Víctor Rafael Hernández-Mendible*

Universidad Monteávila

Universidad Católica Andrés Bello

Caracas, Venezuela

victor@hernandezmendible.com

\title{
La evolución jurisprudencial de la responsabilidad de la Administración Pública en Venezuela**
}

Jurisprudential evolution of Public Administration liability in Venezuela

Doctor en Derecho. Profesor-Director del Centro de Estudios de Regulación Económica en la Universidad Monteávila; Profesor-Coordinador del Diplomado en Derecho Público en la Universidad Católica Andrés Bello (Venezuela) e invitado en la Maestría de la Universidad Externado de Colombia.

\section{Resumen}

El estudio nos propone una revisión crítica sobre el principio de la responsabilidad de los órganos que ejercen el Poder Público desde una doble perspectiva: por una parte, el análisis del régimen jurídico de la responsabilidad de los órganos que ejercen la función administrativa en Venezuela y, por otra, la sistematización de las principales tendencias jurisprudenciales sobre el sistema de responsabilidad de la Administración Pública, desde el nacimiento de la República venezolana hasta las primeras décadas del siglo XXI.

\section{Palabras claves}

Estado de Derecho - Poderes Públicos - Administración Pública - Responsabilidad pública

\footnotetext{
" Artículo recibido el 18 de junio de 2015 y aceptado para su publicación el 20 de noviembre de 2015 .
} 


\begin{abstract}
This study proposes a critical review of the principle of the liability of the Public Power organs, from two views: at first, the analysis of the legal regime of the liability of the organs exercising administrative functions in Venezuela, and by the other side, systematization of the major jurisprudential trends on the liability system of public administration, since the birth of the Republic of Venezuela until the early decades of the century.
\end{abstract}

\title{
Key words
}

Rule of Law - Public authority - Public Administration - State Liability

\section{Introducción}

La consolidación del Estado venezolano como República independiente tiene su origen político jurídico en los sucesos del día 19 de abril de 1810, cuando los integrantes del Cabildo de Caracas se constituyen en "Suprema Junta Conservadora de los Derechos de Fernando VII" y proceden a desconocer la Junta Central, que ejercía la Regencia en España por autoproclamación, y resuelven establecer un gobierno autónomo en la Provincia de Caracas e invitar al resto de las provincias que integraban el territorio de la Capitanía General de Venezuela, para la conformación de un Congreso Nacional en que participarán los representantes de sus respectivos gobiernos ${ }^{1}$.

Estos sucesos desembocarán un año después en la aprobación, por el Congreso, de la Declaración de la Independencia, el 5 de julio de 1811 y la firma de su Acta varios días después, constituyéndose esta en el documento político jurídico fundacional de la República de Venezuela, que aprobaría su primera Constitución Política, el 21 de diciembre de $1811^{2}$ -anterior a la Constitución de Cádiz de 1812-, asumiendo como forma de organización de las provincias, la "Confederación".

Fue luego de 136 años, el 5 de julio de 1947, que Venezuela se establece como un Estado democrático y social de Derecho, lo que ha sido ratificado por la reforma de la Constitución de 30 de diciembre de 1999 vigente. Esta constituye la declaración jurídica más acabada del supraprincipio republicano de gobierno democrático, que se sustenta en los subprincipios: Legalidad, Respeto a las situaciones jurídicas subjetivas, Separación de los órganos que ejercen el Poder Público, Responsabilidad de tales órganos por su actividad e inactividad y Universalidad del control jurisdiccional. 
A los efectos del presente trabajo, el análisis se centrará en el principio de la responsabilidad de los órganos que ejercen el Poder Público. Desde las disposiciones fundamentales de la Constitución se reconoce la responsabilidad del gobierno de la República ${ }^{3-4}$, aunque hubiese sido más adecuado usar la expresión de "los órganos que ejercen el Poder Público", dado que lo planteado como principio es la responsabilidad de todos los órganos 5 .

La responsabilidad del Estado como sujeto de derechos y obligaciones que encarnaba la personificación jurídica de la Nación ${ }^{6}$, se manifiesta a nivel internacional, en general, por incumplimiento de las obligaciones internacionales válidamente contraídas por la entidad política-territorial denominada República ${ }^{7}$ y, en particular, por la violación de derechos humanos que, por actuación u omisión, le sean imputables ${ }^{8}$; y a nivel nacional, responde por la actividad, inactividad o errores que causen daños a las personas privadas y que sean imputables a la República en ejercicio de la función legislativa ${ }^{9}$, de la función jurisdiccional ${ }^{10} \mathrm{o}$ de la función administrativa ${ }^{11}$.

En consecuencia, luego de transcurridos 200 años de vida republicana, tienen similar significación los términos Estado y República ${ }^{12}$, siendo esta la comúnmente empleada para referirse a la persona jurídica que tiene la obligación de responder por la actividad e inactividad imputable a sus órganos, y que genera como contrapartida el derecho subjetivo de las personas a exigir y obtener una justa indemnización, resarcimiento, reparación o reintegro en su esfera jurídica, conforme al ordenamiento jurídico.

Ello así, dado que el estudio de la responsabilidad de los órganos que ejercen la función legislativa y la función jurisdiccional en nombre de la República excede el objeto de este trabajo, el desarrollo del mismo se circunscribirá al análisis de la responsabilidad de los órganos que ejercen la función administrativa en nombre de la República.

Para una mayor claridad en la exposición de las ideas, el presente estudio se dividirá en los siguientes temas, a saber: II. La responsabilidad y administración pública. Ubicación del tema y fundamentos constitucionales; III. La aplicación del derecho privado o de un derecho público especial; IV. La naturaleza directa o indirecta de la responsabilidad; V.

Esta declaración de dilatado arraigo constitucional, se remonta al artículo 6 de la Constitución de 24 de septiembre de 1830, que declaraba que "El Gobierno de Venezuela es y será siempre republicano, popular, representativo, responsable yalternativo".

4 Artículo 6 de la Constitución de 30 de diciembre de 1999, enmendada el 20 de febrero de 2009.

5 Sostiene Gordillo que justamente lo que caracteriza a un Principio es que tiene un contenido tan fuerte y tan profundo, que su aplicación debe ser extensiva y desbordar el simple marco de interpretación literal, determinando así de forma integral, cuál debe ser la orientación de la institución por el que se ejecuta. Gordillo, Agustín (1998), p. 260.

Corte Federal y de Casación, en Sala Federal, sentencia de 8 de febrero de 1939.

Artículo 155 de la Constitución.

Artículo 30 de la Constitución.

Artículo 6 de la Constitución.

Artículo 49.8 de la Constitución.

Artículo 140 de la Constitución.

Corte Suprema de Justicia en Sala Político Administrativa, sentencia de 20 de enero de 1983, expresó que “... desde que entró en vigencia la actual Constitución [23 de enero de 1961], en el campo jurídico venezolano tienen igual significación los términos de República y Estado, aunque esta última expresión será preferentemente empleada cuando se trate de distinguir las actividades públicas de las actividades privadas". 
La responsabilidad por actos administrativos; VI. La responsabilidad y discrecionalidad; VII. La responsabilidad por retardo en la expedición de actos administrativos; VIII. La responsabilidad por actividad lícita; IX. La responsabilidad por actividad material; X. La responsabilidad por aplicación de la teoría del riesgo creado; XI. La responsabilidad por daños causados por las cosas; XII. La responsabilidad precontractual y contractual; XIII. La responsabilidad por violación de normas internacionales; XIV. La responsabilidad por daño moral; XV. El nexo de causalidad; XVI. El daño injusto; XVII. El derecho a la indemnización integral; XVIII. La corrección monetaria de la indemnización; XIX. Los datos estadísticos: cantidad de procesos y cantidad de condenas; y, por último, XX. Consideraciones finales.

\section{La responsabilidad y Administración Pública. Ubicación del tema y fundamentos constitucionales}

La responsabilidad de la Administración Pública constituye en la actualidad uno de los pilares que sustentan el Estado democrático de Derecho en el mundo occidental y, en el caso concreto del continente americano, se estableció en la Carta Democrática Interamericana como uno de los componentes fundamentales del ejercicio de la democracia, al exigir la responsabilidad de los gobiernos en la gestión pública ${ }^{13}$.

Visto así, se puede considerar, sin duda alguna, que la responsabilidad de la Administración Pública constituye un Principio general de Derecho ${ }^{14}$ que, como se ha advertido, genera la obligación de responder y el derecho subjetivo de las personas a exigir y obtener una indemnización, reparación o restitución integral.

La vigente Constitución de 1999 es continuadora de su antecesora, la Constitución de 1961, y también reconoce, tanto sustantiva como procesalmente, la responsabilidad de la Administración Pública ${ }^{15}$.

En efecto, desde el punto de vista sustantivo, existen dos artículos que expresamente establecen la responsabilidad de la Administración Pública. El primero es el artículo 140 que textualmente dispone:

"El Estado responderá patrimonialmente por los daños que sufran los o las particulares en cualquiera de sus bienes y derechos, siempre que la lesión sea imputable al funcionamiento de la Administración Pública".

13 Artículo 4 de la Carta Democrática Interamericana, suscrita el 11 de septiembre de 2001, en Lima, capital de Perú, por todos los países de América.

14 HernándeZ-Mendible (2008), p. 676.

15 Tribunal Supremo de Justicia en Sala Constitucional, sentencia 2818, de 19 de noviembre de 2002, ha sostenido que “... no existiendo ruptura en la continuidad constitucional de la Constitución de 1961 y la sucesiva de 1999; ni existiendo tampoco en la vigente Constitución de 1999 ninguna limitación ni restricción en cuanto al régimen de responsabilidad del Estado, habría de aplicarse in integrum al caso que nos ocupa, el régimen de responsabilidad contenido en la vigente Constitución de la República...." 
La segunda de las disposiciones constitucionales que contiene una referencia sustantiva de la responsabilidad, es el artículo 141 que expresa:

"La Administración Pública está al servicio de los ciudadanos y ciudadanas y sefundamenta en los principios de honestidad, participación, celeridad, eficiencia, eficacia, transparencia, rendición de cuentas y responsabilidad en el ejercicio de la función pública, con sometimiento pleno a la ley y al Derecho".

Ambas disposiciones son lo suficientemente diáfanas al reconocer la responsabilidad de la Administración Pública frente a los particulares, por los daños que les causen a estos en ejercicio de la función pública administrativa.

Ahora bien, el reconocimiento de esta obligación constitucional de responder, demanda el establecimiento de las garantías jurídicas idóneas para exigir dicha responsabilidad. Es así como el artículo 259 de la Constitución, desde la perspectiva procesal, establece lo siguiente:

"La jurisdicción contencioso administrativa corresponde al Tribunal Supremo de Justicia y a los demás tribunales que determine la ley. Los órganos de la jurisdicción contenciosoadministrativa son competentes para anular los actos administrativos generales o individuales contrarios a Derecho, incluso por desviación de poder, condenar al pago de sumas de dinero y a la reparación de daños y perjuicios originados en responsabilidad de la Administración; conocer de reclamos por la prestación de servicios públicosy disponer lo necesario para el restablecimiento de las situaciones jurídicas subjetivas lesionadas por la actividad administrativa".

En tales términos, la Constitución define claramente que será el orden jurisdiccional administrativo -no otro- el competente para determinar la responsabilidad de la Administración Pública, en virtud de lo que podrá: en primer lugar, condenar al pago de sumas de dinero; en segundo lugar, ordenar la reparación de daños y perjuicios derivados de dicha responsabilidad; y en tercer término, disponer lo necesario para el restablecimiento de las situaciones jurídicas subjetivas lesionadas por la actividad administrativa.

Conforme a ello, toda persona puede acudir a los órganos jurisdiccionales administrativos para lograr la tutela judicial efectiva de sus derechos e intereses, incluso de los colectivos y difusos en los asuntos en que se vean involucrados en sus relaciones con la Administración Pública.

Concretamente, se reconoce la representación que puede ejercer la Defensoría del Pueblo, en nombre de los titulares de derechos colectivos y difusos, para exigir al Estado el resarcimiento de los daños y perjuicios que se ocasionen a las personas, con motivo del funcionamiento de los servicios públicos ${ }^{16}$.

Como se puede apreciar, existe un amplio y sólido fundamento constitucional de la responsabilidad de la Administración Pública y de la atribución de los órganos jurisdiccionales que pueden establecerla, conforme a los términos de distribución de competencias

16 Artículo 281.2 de la Constitución. 
por la cuantía, materia y territorio, establecidos en la Ley Orgánica de la Jurisdicción Contencioso Administrativa.

\section{La aplicación del derecho privado o de un derecho público especial}

Tanto el marco constitucional anterior como el vigente han servido de justificación para que, tanto el histórico voto salvado del Magistrado Farías Mata ${ }^{17}$, como la doctrina científica, advirtieran la existencia de un régimen jurídico de responsabilidad de derecho público, especial, autónomo y propio, distinto del régimen de derecho privado ${ }^{18}$.

Esta posición fue asumida por la jurisprudencia del Máximo Tribunal de la República, que ha encontrado el fundamento de la justificación de la responsabilidad de la Administración Pública en las disposiciones constitucionales, y ha promovido el abandono de los criterios iusprivatistas que nutrieron esta materia en sus orígenes ${ }^{19}$.

Estos criterios ratificados, luego de entrada en vigencia la Constitución de 1999, por la jurisprudencia del orden jurisdiccional administrativo ${ }^{20}$, han sido aceptados por la Sala Constitucional del Tribunal Supremo de Justicia, que ha expresado lo siguiente ${ }^{21}$ :

“... el Estado venezolano puede autolimitar la responsabilidad objetiva a la que sujeta la normativa constitucional el ejercicio de la función pública, ya que esta responsabilidad ni se rige por los principios establecidos en el Código Civil para la regulación de las relaciones horizontales departicular a particular, ni puede ser general o absoluta. Más aún, en aplicación de los principios de transparencia y responsabilidad en el ejercicio de la función pública postulados en el artículo 141 de la Constitución vigente, la responsabilidad contractual y extracontractual del Estado debe tener sus reglas especiales que varian en función de las necesidades del servicio, y de la necesidad de conciliar los derechos del Estado con los derechos privados de los ciudadanos".

17 El Magistrado Luis Henrique Farías Mata señala en el voto salvado a la sentencia de 4 de marzo de 1993, de la Corte Suprema de Justicia en Sala Político Administrativa, que "la responsabilidad patrimonial que puede corresponder a las personas morales de Derecho público por el ejercicio de la actividad administrativa, no es ni general ni absoluta, como se ha dicho en la decisión a menudo considerada - no con todo fundamento- madre del Derecho Administrativo; no se rige, en efecto, directa ni literalmente por las reglas del Código Civil, concebidas para regular las relaciones entre simples particulares; y comporta reglas autónomas y propias, que debe determinar, como ya lo ha hecho, el juez venezolano del contencioso-administrativo, tomando en cuenta la naturaleza del servicio público involucrado, y la necesaria conciliación con el interés general en la prestación del servicio".

18 Iribarren Monteverde (1992); Ortíz Álvarez (2006). p. 333; Araujo-Juárez (2007), p. 1014.

19 Corte Suprema de Justicia en Sala Político Administrativa, sentencia de 23 de noviembre de 1999.

20 Tribunal Supremo de Justicia en Sala Político Administrativa, sentencia 968, de 2 de mayo de 2000; sentencia 2130 de 4 de octubre de 2001 y sentencia 1013, de 30 de julio de 2002.

21 Tribunal Supremo de Justicia en Sala Constitucional, sentencia 2818, de 19 de noviembre de 2002. 
Más recientemente, al volver a analizar el artículo 140 de la Constitución ha insistido en señalar ${ }^{22}$ :

"En este sentido, la evolución asentada por el Constituyente tiene por objeto procurar un verdadero sistema integral y autónomo de derecho público que no dependa de las normas privadas, estructurado sobre una base propia, determinada por regulación especial".

En conclusión, del régimen constitucional de responsabilidad de la Administración Pública tanto la doctrina científica como la jurisprudencia constitucional y administrativa, reconocen la existencia de un marco jurídico de preeminente derecho público, especial, autónomo y propio, que se diferencia claramente del derecho privado.

De allí que éste proponga aplicar en primer término, las disposiciones constitucionales que son norma suprema y fundamento del resto del ordenamiento jurídico, para de manera complementaria aplicar los Principios generales del Derecho Público y únicamente de manera supletoria, en aquello que no pueda ser resuelto aplicando las fuentes anteriores, se admite la posibilidad de acudir a las disposiciones sobre responsabilidad contenidas en el Código Civil, siempre que exista una remisión legal expresa ${ }^{23}$ o que circunstancias particulares así lo exijan ${ }^{24}$.

\section{La naturaleza directa o indirecta de la responsabilidad}

Históricamente, una vez superada la época de inicial rechazo de la responsabilidad de la Administración Pública ${ }^{25}$, comienza el debate para determinar si esta únicamente debe responder directamente frente a los particulares por su propia actividad o inactividad ${ }^{26}$ o si, incluso, debe responder indirectamente por la ilicitud en que hayan incurrido las personas a su servicio, como funcionarios o contratados.

Es así como, en un primer momento, la responsabilidad de la Administración Pública se situó en la exigencia de que se tratase de una actividad o inactividad que le era directamente imputable, sin que existiese intermediación alguna entre ella y la persona afectada por tal conducta, que experimentaba el daño que debía ser resarcido ${ }^{27}$.

Posteriormente, se procedió a admitir la responsabilidad directa y solidaria de la Administración Pública con sus contratistas. El asunto se trata de una empresa contratada por la Administración Pública para realizar una obra y consecuencia de que ejecutó defectuosamente la construcción del edificio, se produjo la muerte de un menor de 4 años

\footnotetext{
Tribunal Supremo de Justicia en Sala Constitucional, sentencia 189, de 8 de abril de 2010

Tribunal Supremo de Justicia en Sala Constitucional, sentencia 1259, de 26 de julio de 2011.

Tribunal Supremo de Justicia en Sala Político Administrativa, sentencia 128, de 7 de febrero de 2013.

Corte Suprema de Justicia en Sala Político Administrativa, sentencia de 14 de noviembre de 1963 y sentencia de 5 de febrero de 1964

26 Procuraduría General de la República, Dictamen de 14 de abril de 1975.

27 Guillermo Andueza (1959), p. 32; Lares Martínez, Eloy (1963), p. 407; Brewer-Carías (1964), pp. 421-422.
} 
de edad. Los padres de la víctima demandaron a ambos y la Corte Suprema de Justicia estableció que ${ }^{28}$ :

"Estima la Sala que en este caso la responsabilidad de los demandados es directa y no objetiva ... (omissis)... Por ello, tanto el propietario del inmueble a quien corresponde la supervisión de la obra, como a la Constructora a quien le correspondía su ejecución, son responsables por este defecto de diseño en las barandas del edificio.... (omissis)... Por todo lo que antecede, la Sala deja establecida la responsabilidad solidaria de los demandados, por el hecho culposo de no haber ofrecido a los habitantes del edificio en referencia, las seguridades que exige la ley y el sentido común, con lo cual el niño Romeld Desangles pudo caer desde el sexto piso perdiendo la vida a consecuencia de hematoma subdural agudo y politraumatismos causados por caida de altura".

En este orden de ideas, se ha admitido que la responsabilidad de la Administración Pública no solo es directa, sino que también puede exigírsele en los supuestos que se trate de daños antijurídicos producidos por sus funcionarios actuando con motivo de sus funciones, aunque fuera del ámbito estricto de sus competencias.

En este caso, para que la persona víctima del daño no quede desprotegida, y en aras de garantizar la integridad de la reparación del daño experimentado, se reconoce al afectado el derecho a elegir si demanda exclusivamente a la Administración Pública, si prefiere ejercer su reclamación únicamente contra el funcionario, o si opta por demandar a ambos de manera solidaria o subsidiaria.

La jurisprudencia, al analizar la naturaleza de la responsabilidad, ha optado por reconocer tanto la directa como la indirecta, tal como se infiere de las sentencias que serán objeto de análisis seguidamente.

En tal sentido, el Tribunal Supremo de Justicia en Sala Político Administrativa ${ }^{29}$ ha sostenido respecto a la naturaleza de la responsabilidad, lo siguiente:

"En la medida de los supuestos descritos, el esquema tradicional se ha hecho insuficiente razón por la cual en la actualidad, atendiendo a principios de derecho público, el acento no está en los criterios de culpa sino en orden de garantizar la reparación de quien sufre el daño antijurídico, basado en los criterios de falta ofalla de servicio e, incluso del riesgo o daño especial (los cuales, a su vez, se fundamentan en losprincipios de equidad, solidaridad social, igualdad ante las cargas públicas, o al hecho de la insolvencia del agente público para responder al daño), que expresan en alto grado un sistema de responsabilidad objetiva, es decir, que en menor o mayor medida atienden al daño causado y donde la responsabilidad del Estado, entendida como indirecta, pasa entonces a ser directa".

Sin mayor aspaviento, esta sentencia considera que la responsabilidad indirecta de la Administración Pública, por motivo de las actuaciones u omisiones imputables a sus

28 Corte Suprema de Justicia en Sala Político Administrativa, sentencia 14 de febrero de 1991.

29 Tribunal Supremo de Justicia en Sala Político Administrativa, sentencia 2130, de 9 de octubre de 2001. 
funcionarios, se transforma en responsabilidad directa en aras de garantizar la reparación integral del daño experimentado por la persona.

Posteriormente, la Sala Constitucional del Tribunal Supremo de Justicia ${ }^{30}$, tuvo oportunidad de pronunciarse en vía de revisión constitucional, sobre la sentencia de la Sala Político Administrativa del mismo Tribunal, que había negado la responsabilidad de la Administración Pública actuando en función de policía de seguridad, exigida por la viuda e hijos de un abogado que fue asesinado por un grupo élite de policías del Cuerpo Técnico de Policía Judicial. En esa oportunidad, a los fines de resolver el asunto planteado la sentencia efectúa las siguientes consideraciones:

"Claro está, que un régimen de responsabilidad objetiva del Estado no puede ser aprioristico y tener los efectos de una presunción iure et de iure a favor de los particulares, ya que pudiera ocurrir que la acción ilicita o delictual del funcionario público no gravara la responsabilidad del Estado pero solo y siempre cuando quedare evidenciado que el móvil y circunstancias del delito quedaron limitadas al ámbito intimo y personalísimo del funcionario; o también, cuando existieren causas de inimputabilidad penal como son el estado de necesidad y la legitima defensa".

Vale la pena destacar cómo la sentencia advierte que la tesis de la responsabilidad indirecta de la Administración Pública, por los daños ocasionados por sus funcionarios, no se aplica en todo caso, ni de manera general, sino que se debe analizar el asunto concreto a los fines de determinar su eventual procedencia.

Seguidamente, reconoce, sin ningún género de dudas, la procedencia de la responsabilidad directa de la Administración Pública, por los daños causados por aquella actividad que le sea imputable. Al respecto señala:

"La consagración con rango constitucional de un régimen amplio, integral y objetivo de responsabilidad patrimonial del Estado constituye, en opinión de esta Sala Accidental Constitucional, una manifestación indudable de que dicho régimen se erige como uno de los principios y garantías inherentes a todo Estado de Derecho y de Justicia, en el que la Administración, a pesar de sus prerrogativas, puede ser condenada a resarcir por via indemnizatoria los daños causados a los administrados por cualquiera de sus actividades".

Luego de establecer las anteriores premisas, la sentencia procede a censurar la decisión objeto de revisión constitucional, expresando lo siguiente:

"En cambio, la Sala Politico-Administrativa haciendo una interpretación restringida del régimen de responsabilidad patrimonial del Estado previsto en la Constitución de la República, y dando mayor relevancia al carácter subjetivo de la conducta de los agentes involucrados y a la integridad del erario público por sobre el carácter objetivo que la Constitución confiere a la responsabilidad del Estado, -criterio respecto del cual esta Sala Accidental Constitucional ya manifestó su desacuerdo-, consideró que los agentes públicos cometieron el hecho dañoso impulsados por razones de odio, venganza y enemistades, actitudes éstas de marcada natu-

30 Tribunal Supremo de Justicia en Sala Constitucional, sentencia 2818, de 19 de noviembre de 2002. 
raleza dolosas que no se corresponden con la prestación del servicio de policia y que excluyen, por tanto, la responsabilidad del Estado, por tratarse del hecho de terceros; llegándose a señalar en la sentencia, que las conductas dolosas de los agentes excluyen la responsabilidad de la Administración incluso cuando éstos hubieren estado en aparente ejercicio de la función pública o actuando con ocasión de la misma (folio. 87 de la sentencia).

Ahora bien, además de insistir en que la interpretación efectuada por la Sala PolíticoAdministrativa para arribar a la conclusión precedentemente expuesta no resulta cónsona y acorde con la intención del Constituyente, al consagrar la responsabilidad del Estado como una garantía a favor del particular, observa esta Sala que la existencia de una falta personal del funcionario no excluye directamente la responsabilidad del Estado, pues cuando esa falta concurra con el servicio, o no esté totalmente desligada del mismo, compromete la responsabilidad patrimonial de la Administración".

Con fundamento en esta afirmación, la sentencia lleva a la inequívoca conclusión que la responsabilidad de la Administración Pública no solo es directa cuando la actuación sin mediación alguna le sea imputable a ella, sino que también se puede ver comprometida directamente por la conducta antijurídica de sus funcionarios, cuando estos hayan actuado en ejercicio de sus atribuciones o con motivo de sus funciones.

En tal virtud, la Sala Constitucional en la sentencia de revisión constitucional deja zanjada la discusión sobre si la responsabilidad de la Administración es de naturaleza directa o indirecta, pues en principio siempre se va producir la primera, cuando la actividad o inactividad sea imputable directamente a la Administración Pública.

Por otra parte, la actuación ilícita, irregular, desviada, torcida o dolosa de los funcionarios públicos no puede conducir apriorísticamente a eximir de responsabilidad a la Administración Pública, sino que corresponderá evaluar las circunstancias en que se produjo el daño, para determinar la procedencia de la responsabilidad indirecta, para lo cual el órgano jurisdiccional siempre debe actuar orientado a garantizar la reparación integral del daño y sin perjuicio del derecho de repetición de lo pagado indebidamente que asiste a la Administración Pública con respecto al funcionario y que ha sido analizado en otra ocasión al estudiar las responsabilidades de éste frente a aquélla ${ }^{31}$.

En este mismo orden de ideas, se planteó el caso de una persona bajo la custodia de tres funcionarios policiales que, teniendo la detenida porque presuntamente había sido el autor material de la muerte de otro funcionario de la Policía de Caraca resultó lesionada en la región frontal de la cara, como consecuencia de un disparo con un revólver calibre 38, cuando se encontraba en el área de reseña durante la guardia que realizaban los tres funcionarios, en las instalaciones de la Policía de Caracas del Municipio Libertador, lo que condujo al inicio de un proceso penal en que el autor del disparo fue condenado por homicidio intencional en grado de frustración y los otros dos funcionarios por el mismo delito en grado de complicidad.

31 HernándeZ-Mendible (2011), pp. 403-448, en especial, pp. 442-445. 
La víctima demandó al municipio por los daños y el Tribunal Supremo de Justicia, luego de advertir que los funcionarios "actuaron valiéndose de los medios e instrumentos inherentes a su condición de prestadores del servicio de policía”, señala respecto a la responsabilidad de la Administración lo siguiente ${ }^{32}$ :

“iii) A los efectos de la responsabilidad patrimonial de la Administración Pública, los hechos culposos o dolosos de los agentes policiales no pueden considerarse desvinculados del servicio depolicia por ellosprestados, cuando precisamente en virtud de tal actividad se hayan creado las condiciones para la realización del hecho ilicito y la producción de sus consecuencias perjudiciales;

iv) La existencia de una falta personal del funcionario no excluye directamente la responsabilidad del Estado, pues cuando esa falta concurra con el servicio o no esté totalmente desligada del mismo, compromete la responsabilidad patrimonial de la Administración;...”.

A partir de esta idea concluirá que, consecuencia del hecho dañoso vinculado al servicio de policía llevado a cabo de manera ajena al deber que tenían los funcionarios, al actuar éstos investidos de las funciones en la policía municipal, se ha producido un funcionamiento anormal atribuible al Instituto Autónomo de Seguridad Ciudadana y Transporte del Municipio Libertador del Distrito Capital, que compromete su responsabilidad directa en el presente asunto.

Más reciente, el Tribunal Supremo de Justicia en Sala Político Administrativa, ha vuelto a analizar la responsabilidad de la Administración Pública derivada de la actividad e inactividad imputable a sus contratistas y en tal sentido ha expresado ${ }^{33}$ :

“...sin embargo, existen otros casos como el de autos, en los que la responsabilidad del Estado surge de forma refleja, o lo que es lo mismo, el daño se origina al mediar la intervención de un tercero, supuestos en los que resulta necesario acudir, no solo a la regla general de responsabilidad antes comentada, sino también a los supuestos de responsabilidad civil que tienen una regulación especifica.

Así, esta Sala advierte que la pretensión de la parte actora se apoya en la denuncia de un supuesto hecho ilícito que atribuye a un ente que integra la Administración Pública, de manera indirecta, esto es, por intermedio de terceros. Por ello, considera este Alto Tribunal que la procedencia de una indemnización por los daños morales que se le han imputado al Instituto Venezolano de los Seguros Sociales, derivados del deterioro de la salud física y mental de los accionantes, como consecuencia de un accidente químico generado por sus contratistas, puede analizarse a la luz de los artículos 1.185 y 1.191 del Código Civil, en los cuales se fundamentó la demanda”.

En este caso, el Tribunal considera que, si bien existe una responsabilidad indirecta o refleja de la Administración Pública, por una actividad imputable a un contratista, la misma debe ser analizada bajo el prisma del Derecho Privado, en lugar de las reglas de

32 Tribunal Supremo de Justicia en Sala Político Administrativa, sentencia 962, de 6 de octubre de 2010, ratificada por la sentencia 1072, de 3 de noviembre de 2010.

33 Tribunal Supremo de Justicia en Sala Político Administrativa, sentencia 128, de 7 de febrero de 2013. 
Derecho Público que se han mencionado anteriormente. Este sería uno de los supuestos excepcionales, según esta sentencia, en que se aplican disposiciones de Derecho Privado para determinar la responsabilidad de la Administración Pública.

\section{La responsabilidad por actos administrativos}

La Constitución establece que la Administración Pública se encuentra al servicio de los ciudadanos y debe actuar orientada a la satisfacción del interés general, con sometimiento pleno a la Ley y el Derecho ${ }^{34}$.

La Administración Pública, en ejercicio de las competencias legalmente atribuidas, puede ejecutar actuaciones dirigidas a realizar los fines que tiene encomendados, cuyas consecuencias terminen afectando a las personas y generando en ellas el derecho a obtener una indemnización.

Así lo ha reconocido la Corte Suprema de Justicia, al admitir la posibilidad de derivar la responsabilidad de la Administración Pública de los actos administrativos por ella expedidos. En tal sentido, había advertido lo siguiente ${ }^{35}$ :

“... esta Sala estima necesario pronunciarse - previo a cualquier otra consideración-respecto de la posibilidad de demandar el pago de daños y perjuicios que tengan su origen en actos administrativos. Al respecto, primero se requiere destacar que la evolución de la teoría de la responsabilidad patrimonial del Estado, no deja lugar a dudas sobre la extensión de tal responsabilidad. Efectivamente, la responsabilidad del Estado ha evolucionado desde la situación inicial de irresponsabilidad total, hasta la ampliación tal de su responsabilidad, alpunto que se ha aceptado la responsabilidad por riesgo objetivo. Asi, no existen entonces en la actualidad dudas sobre la posibilidad de exigir la responsabilidad del Estado, lo que inclusive puede dar lugar a la exigencia de indemnización por daños producidos por actos administrativos".

Los actos administrativos pueden ser lícitos y producir daños, como sucede en los casos de los decretos de afectación para ejecutar las expropiaciones, que conllevan el pago de una justa y oportuna indemnización, o pueden ser ilícitos, en cuyo caso será necesaria la declaratoria de la ilegalidad, previamente reconocida por la autoridad administrativa competente en ejercicio de la potestad de autotutela o por el órgano jurisdiccional, para luego pretender la correspondiente indemnización.

35 Corte Suprema de Justicia en Sala Político Administrativa, sentencia de 25 de enero de 1996. 


\section{La responsabilidad y la potestad discrecionalidad}

La doctrina científica había advertido mucho antes de la vigencia de la Ley Orgánica de Procedimientos Administrativos, que la potestad discrecional de la Administración Pública no implicaba arbitrariedad y, una vez entrada en vigor dicho texto, este dispuso que ${ }^{36}$ : "Aun cuando una disposición legal o reglamentaria deje alguna medida o providencia a juicio de la autoridad competente, dicha medida o providencia deberá mantener la debida proporcionalidad y adecuación con el supuesto de hecho y con los fines de la norma, y cumplir los trámites, requisitos y formalidades necesarias para su validez y eficacia".

El reconocimiento de tal potestad discrecional a la Administración Pública ha sido objeto de relevante análisis, tal como lo recoge la jurisprudencia de la Corte Suprema de Justicia $^{37}$, al exigir su sujeción a la legalidad administrativa.

En este orden de ideas, el Máximo Tribunal de la República, al realizar el control sobre la actividad discrecional de la Administración Pública, ha reconocido su responsabilidad en los siguientes términos ${ }^{38}$ :

"Ya se ha señalado con anterioridad que el acto administrativo dictado el 31 de diciembre de 1969 creó a favor de la accionante el derecho de importar y, como consecuencia del mismo, obtuvo una bonificación ya establecida. El otorgamiento de ese permiso si constituye un acto «discrecional» en el sentido en que lo ha entendido este Supremo Tribunal (véase sentencia, S-P-A., de 2-11-82, «Depositaria Judicial»), perfectamente acorde, por lo demás, con las prescripciones del artículo 12 de la hoy vigente Ley Orgánica de Procedimientos Administrativos, acto que, como tal, la Administración Pública puede acordar o no, con arreglo a razones de oportunidad o conveniencia, como serían la necesidad de proveer al pais, durante un lapso prefijado, de ciertos bienes que en un momento determinado no se produzcan, o se produzcan en una escala reducida. De alli el incentivo que se acuerde a través de una bonificación.

Ahora bien, a partir del momento en el que la Administración acuerda el permiso de importación y se determina el monto de la bonificación, creándose de esta manera derechos a favor de los particulares, no puede hablarse de discrecionalidad en la ejecución del acto lícitamente emitido ya, bien que con arreglo a poderes discrecionales; en otras palabras, al cumplirse el supuesto de hecho, la administración está obligada al pago de la bonificación. Por esa misma circunstancia, tal acto creador de derechos a favor de un particular no podía, en el caso de autos, ser objeto de revocación o modificación, asi se declara".

En razón de tales argumentos, la sentencia dispuso que, habiéndose producido la importación conforme al permiso dictado en ejecución de una potestad discrecional y durante el tiempo de su vigencia, el demandante tenía el derecho adquirido a recibir el pago de dinero por concepto de bonificación, que le debía ser pagado por la República.

\footnotetext{
Artículo 12 de la Ley Orgánica de Procedimientos Administrativos.

Corte Suprema de Justicia en Sala Político Administrativa, sentencia de 2 de noviembre de 1982.

Corte Suprema de Justicia en Sala Político Administrativa, sentencia de 9 de abril de 1987.
} 
Tal criterio permite reiterar la posición de la doctrina científica y la jurisprudencia del orden jurisdiccional administrativo, según la cual los actos administrativos creadores de derechos que sean dictados en ejercicio de competencias preeminentemente regladas o predominantemente discrecionales, no pueden ser revocados y, en caso de producirse esta última actuación, el acto administrativo revocatorio se encontraría viciado de nulidad absoluta $^{39-40}$.

Pero lo más importante consiste en ratificar el establecimiento del límite al ejercicio de la potestad discrecional de la Administración Pública, que en ningún caso puede implicar arbitrariedad y que, en caso de exceder tales límites - proporcionalidad, razonabilidad y adecuación-, ello deriva en la responsabilidad de la Administración Pública.

\section{La responsabilidad por retardo en la expedición de actos administrativos}

Anteriormente se ha señalado que, con fundamento en las disposiciones constitucionales, los particulares tienen derecho a exigir la responsabilidad por los daños experimentados personalmente, en sus bienes o derechos, cuando tal lesión sea imputable al funcionamiento de la Administración Pública ${ }^{41}$.

Esta fórmula constitucional debe ser interpretada y aplicada de manera congruente con aquella que le otorga al órgano jurisdiccional administrativo la competencia para condenar al pago de sumas de dinero, la reparación de daños y perjuicios generados por la responsabilidad de la Administración Pública, y ordenar el restablecimiento de la situación jurídica subjetiva lesionada por la actividad administrativa ${ }^{42}$.

Ahora bien, conforme al principio de universalidad del control jurisdiccional, no existe actividad o inactividad imputable a la Administración Pública que escape al pronunciamiento de los órganos jurisdiccionales administrativos, razón por la cual la demora o retardo injustificados en la expedición de los actos administrativos o, incluso, en el cumplimiento de obligaciones derivadas del ordenamiento jurídico, se encuentran sometidas al pronunciamiento de tales tribunales.

Es el caso que, al producirse el retardo o demora en la producción de un acto administrativo o el incumplimiento de una obligación, la persona afectada en ejercicio del derecho a la tutela judicial efectiva puede acudir ante el órgano jurisdiccional con fundamento en el principio de integridad patrimonial, para formular la pretensión de condena contra la Administración Pública y exigir tanto la producción del acto, el cumplimiento de la obligación jurídica y la indemnización o reparación que sea procedente por concepto de

\footnotetext{
Artículos 11, 19.2 y 82 de la Ley Orgánica de Procedimientos Administrativos.

Corte Suprema de Justicia en Sala Político Administrativa, sentencia de 14 de mayo de 1985.

Artículo 140 de la Constitución.

Artículo 259 de la Constitución.
} 
daños y perjuicios, tal como se infiere de los artículos constitucionales mencionados. En tal sentido se había pronunciado la Corte Suprema de Justicia, en los siguientes términos ${ }^{43}$ :

"Ahora bien, es necesario destacar que el incumplimiento de una Administración de una obligación legal de actuación especifica tal que un sujeto de derecho posea un derecho subjetivo administrativo a dich a actuación, puede producir daños al sujeto a favor de quien la norma concreta estipulaba la realización de la conducta omitida. Los daños aludidos pueden haberse producido tanto por retardo de la obligación especifica y concreta de actuar, como por su incumplimiento y en ambos casos los daños producidos en forma directa e inmediata por la omisión de la Administración de realizar una conducta especifica, deben ser indemnizados. ...omissis... En consecuencia, sólo será procedente el pago de daños y perjuicios ocasionados por abstenciones de la Administración cuando dichos daños sean la consecuencia inmediatay necesaria de la inactividad de la Administración, en cuyo caso, dichos dañosserán requeridos por el sujeto como una pretensión de condena y no como una acción diferenciada de la original".

La sentencia antes citada reconoce sin duda alguna, la responsabilidad imputable a la Administración Pública por su inactividad, admitiendo la posibilidad de acumular a una pretensión de condena a hacer o actuar, el pago de los daños derivados de tal omisión, demora o incumplimiento, todo en la misma demanda.

Se debe mencionar que, posteriormente, la posición jurisprudencial ha variado, en el sentido de negar la posibilidad de acumular la pretensión de condena a actuar o hacer, con la pretensión de pago de sumas de dinero en una misma demanda y por ende su tramitación en un solo proceso ${ }^{44}$, lo que no parece ajustarse a la disposición constitucional que reconoce el orden jurisdiccional administrativo.

No obstante, la reciente reforma del proceso administrativo admite la posibilidad de formular las demandas que contengan pretensiones de condena a expedir un acto administrativo o cumplir una obligación jurídica a través del proceso breve, debiendo formularse separadamente la demanda de pagos de sumas de dinero en el proceso de contenido patrimonial, es decir, es posible exigir la responsabilidad de la Administración Pública por demora, retardo en la emisión de actos o incumplimiento de obligaciones, con fundamento en las disposiciones constitucionales mencionadas, pero únicamente a través del proceso de demandas de contenido patrimonial establecido para tal fin ${ }^{45}$.

\section{La responsabilidad por actividad lícita}

Los órganos que ejercen el Poder Público en ejercicio de sus competencias normalmente deben desarrollar una actividad lícita, conforme al ordenamiento jurídico, que puede incidir en la esfera jurídica de las personas, modificando, extinguiendo o afectando derechos o intereses de estas.

43 Corte Suprema de Justicia en Sala Político Administrativa, sentencia de 21 de abril de 1999.

44 Tribunal Supremo de Justicia en Sala Político Administrativa, sentencia 838, de 11 de agosto de 2010.

45 Artículos 56 al 74 de la Ley Orgánica de la Jurisdicción Contencioso Administrativa. 
Existen supuestos donde esa actuación lícita de la Administración Pública debe ser soportada, tolerada y aceptada por las personas que se ven afectadas por ella, como sucede cuando se produce el comiso de bienes producto de un contrabando, y existen otros casos, donde, a pesar de la actuación lícita de la Administración Pública, se impone un sacrificio para la persona, que excede de aquel que el común de las personas deben normalmente soportar y que, en virtud de su magnitud, anormalidad y singularidad, conduce a una ruptura del principio de igualdad ante las cargas públicas, que exige una compensación por el sacrificio irrogado en provecho del interés general que ha justificado la actuación de la Administración Pública.

Al respecto se había pronunciado la Corte Suprema de Justicia en su sentencia líder ${ }^{46}$, al expresar que "los textos constitucionales y legales no circunscriben la indemnización únicamente a la pérdida de la propiedad por expropiación, o por los hechos ilícitos de la Administración, sino que se extienden a cualquier lesión a derechos o intereses legítimos, por ejemplo, las privaciones singulares de los atribuciones esenciales de la propiedad, a pesar de que provengan de sus actos lícitos" y, ampliando esta argumentación, sostiene que existe “... el deber de indemnizar por parte de la Administración, derivados de su responsabilidad en general o por la actuación de sus funcionarios competentes, de donde se desprende su obligación de indemnizar los daños causados a los particulares, aun por sus actos lícitos, como serían los emanados de dichos funcionarios", tesis esta que sería reiterada luego por la propia Sala Político Administrativa ${ }^{47}$.

De lo que se trata es que la Administración Pública asuma las consecuencias de su actividad lícita, pero jurídicamente dañosa para determinadas personas y debe proceder a indemnizarlas por ello, tal como lo ha reconocido el Tribunal Supremo de Justicia, en su jurisprudencia reiterada. $\mathrm{Al}$ respecto se puede citar lo siguiente ${ }^{48}$ :

“...la Administración está obligada, en principio, al resarcimiento en toda circunstancia: sea por su actuación ilegitima; o bien porque en el ejercicio legitimo de sus competencias genere daños a los administrados. En consecuencia, la actividad de la Administración, manifestada a través de cualquiera de sus instituciones mediante las cuales gestiona la prestación de servicios públicos, debe siempre resarcir a los particulares, si por el resultado de su actuación se fractura el equilibrio social, alterando la necesaria igualdad que debe prevalecer entre los ciudadanos ante las cargas públicas, denominado por la doctrina responsabilidad sin falta 0 por sacrificio particular; o porque en virtud de la misma gestión pública, el daño se produce como resultado de un funcionamiento anormal de la Administración...".

Reiterando, la obligación de resarcimiento en caso de actuación lícita, entre otros criterios, en virtud del principio de la igualdad ante las cargas públicas, sostiene el Máximo Tribunal lo siguiente ${ }^{49}$ :

Corte Suprema de Justicia en Sala Político Administrativa, sentencia de 27 de enero de 1994

Corte Suprema de Justicia en Sala Político Administrativa, sentencia de 25 de enero de 1996.

Tribunal Supremo de Justicia en Sala Político Administrativa, sentencia 1210, de 3 de octubre de 2002; reiterada en sentencia 128, de 7 de febrero de 2013.

49 Tribunal Supremo de Justicia en Sala Político Administrativa, sentencia 730, de 30 de junio de 2004. 
“...En efecto, esta Sala ha precisado que la responsabilidad del Estado encuentra actualmente fundamento expreso en los Principios de Igualdad, Solidaridad y Justicia Social o de Equilibrio ante las Cargas Públicas, los cuales se sustentan en el postulado de persecución, consecución, satisfacción y tutela de los intereses colectivos, por parte de las instituciones del Poder Público y sus órganos; motivo por el cual, si alguna autoridad legítima causa daños o perjuicios a un particular en el ejercicio legal o ilegal de sus potestades públicas, éste último no debe de sufrir individualmente las cargas de esa actividad administrativa, ya que un sujeto que forma parte del colectivo no debe ser sometido a una situación más gravosa de la que soportan la generalidad de los ciudadanos. En tal supuesto negado, el equilibrio debe ser restablecido mediante la indemnización correspondiente, aunque la actividad administrativa fuese lícita o se presuma que es de tal forma, sí causó de manera excepcional un daño o perjuicio cierto".

Esta posición jurisprudencial ha llevado a la doctrina científica a reconocer la responsabilidad de la Administración Pública por actuación lícita frente a una persona o grupo de ellas, por el sacrificio particular o singular, es decir, por afectación, lesión o restricción a los derechos, más allá de lo racional o tolerable para una persona individual o singularmente considerada, ante el beneficio que tal sacrificio concreto produce en la colectividad ${ }^{50}$.

\section{La responsabilidad por actividad material}

Estando establecido que la actividad formal y la inactividad pueden generar daños a los bienes y derechos de las personas y producir responsabilidad de la Administración Pública; debe advertirse que existen supuestos donde tal responsabilidad no deriva de actuaciones formales o de inactividad (material o formal), sino de actuaciones materiales antijurídicas que lesionan a las personas en su esfera jurídica y que, por tanto, deben ser indemnizadas.

Como ejemplo de ello se puede mencionar el asunto antes reseñado, de los policías que valiéndose de su condición de tales, asesinaron a un abogado en la ciudad de Caracas. En ese caso, se trataba de una actuación material relacionada con la función administrativa de policía de seguridad pública, funcionarios quienes, en lugar de proteger la vida de la persona, sin justificación jurídica alguna, la privaron de ella; al analizar el caso, la Sala Constitucional sostiene que se trata de un típico supuesto de responsabilidad de la Administración Pública, en los siguientes términos ${ }^{51}$ :

"En ese sentido, trasladando las consideraciones precedentes al caso concreto, esta Sala observa que del análisis del acervo probatorio se desprenden indicios suficientes que la llevan a la convicción de que el hecho dañoso que culminó con el homicidio del ciudadano Ramón Carmona Vásquez fue ejecutado por los agentes involucrados valiéndose y aprovechándose de los medios, instrumentos y poderes que su condición de funcionarios prestadores del servicio de policia les brindaba. Concretamente, los funcionarios se sirvieron del vehiculo que era propiedad del Estado, de las armas que como funcionarios policiales tenian asignadas y de

50 Araujo-Juárez (2007), pp. 1031-1032.

51 Tribunal Supremo de Justicia en Sala Constitucional, sentencia 2818, de 19 de noviembre de 2002. 
su posición dentro del organismo policial con el fin de establecer tácticas dirigidas al desvio de las investigaciones.

Estas circunstancias constituyen, en criterio de esta Sala, razones más que suficientes para afirmar que el hecho dañoso cometido por los agentes públicos involucrados no estuvo desprovisto de todo vinculo con el servicio de policía, a cuya prestación con parámetros medios de calidad estaba obligada la Administración, a tenor de lo establecido en el ordinal 6 del articulo 156 de la Constitución, razón por la cual estima esta Sala que el Estado si resulta responsable por los daños derivados del homicidio del ciudadano Ramón Carmona Vásquez, cometido por agentes de policía. Asi se declara”.

Es así como la actuación material imputable a la Administración Pública, cuando produce un daño injusto como, sin duda, lo constituye el caso analizado, compromete su responsabilidad y genera la obligación de reparación integral del daño ${ }^{52}$ en cuanto ello sea posible, dado que, en tal caso, la orden judicial jamás podrá restablecer la vida de la víctima.

\section{La responsabilidad por aplicación de la teoría del riesgo creado}

La teoría del riesgo creado ha sido invocada por la doctrina científica para afirmar que cuando "la Administración en el ejercicio de su misión, expone a algunas personas a un riesgo particular; el riesgo se realiza sin falta de parte: el juez le impone, en ciertas hipótesis la obligación de indemnizar. El hecho generador consiste en la realización del riesgo voluntariamente creado". Los casos más significativos serían los accidentes de trabajo ocasionados a los funcionarios de la Administración Pública, los daños causados por actividades técnicas o cosas peligrosas ${ }^{53}$.

Esta teoría parte de la premisa de que toda persona que genera un riesgo en su propio beneficio se encuentra obligada a reparar los daños causados, en la medida de tal beneficio y del empobrecimiento de quien experimenta los daños. Ahora bien, en el caso que sea la Administración Pública quien genera el riesgo en beneficio del interés general, del cual es vicaria, le corresponderá a ella asumir la responsabilidad de resarcir los daños que tal riesgo haya generado.

La Corte Suprema de Justicia comenzó a admitir la teoría del riesgo creado a los efectos de determinar la responsabilidad de la Administración Pública, como consecuencia de los daños producidos por las empresas públicas operadoras de las infraestructuras para la prestación del servicio eléctrico. $\mathrm{Al}$ respecto sostuvo que ${ }^{54}$ :

“...la responsabilidad se hace aún más evidente cuando se trata de cosas que representan un peligro objetivo del cual ese guardián obtiene un beneficio. Por ejemplo, el caso de la

52 Tribunal Supremo de Justicia en Sala Político Administrativa, sentencia 608 del 9 de junio de 2004, ratificada por la sentencia 1047, de 28 de octubre de 2010.

53 Rivero (1984), pp. 308-309.

54 Corte Suprema de Justicia en Sala Político Administrativa, sentencia de 5 de abril de 1994. 
existencia de un depósito de explosivos en una empresa del ramo, situación que determina la existencia de un riesgo objetivo del cual se beneficia la citada empresa. Si se trata de una cosa peligrosa, dentro de las cuales podemos incluir sin duda a la electricidad, y aun más la de alta tensión, de la cual el guardián saca un provecho, resulta obvio que debe asumir totalmente las consecuencias que deriven del riesgo que crea".

Sin embargo, al analizar el caso relacionado con el atentado terrorista contra algunos de los magistrados de la antigua Corte Suprema de Justicia, que le causaron lesiones permanentes a uno de los empleados de dicho órgano jurisdiccional, el Tribunal Supremo de Justicia se pronuncia efectuando las siguientes consideraciones ${ }^{55}$ :

"Ahora bien, debe señalarse que en el pasado la doctrina consideró que el fundamento de esta responsabilidad se encontraba en la Teoría del Riesgo, conforme a la cual, quien se beneficie de una actividad deberá soportar las consecuencias que de ésta se deriven. Dicha concepción no se encuentra totalmente superada, ni tampoco es incompatible con el régimen de responsabilidad administrativa a que se ha hecho referencia por tener su origen en el Derecho Civil. Lo que ocurre es que, existiendo un fundamento constitucional que de manera expresa apoye la responsabilidad extra-contractual administrativa (Principio de Igualdad o equilibrio ante las Cargas Públicas), no es necesario acudir a otra razón o explicación de ésta”.

La sentencia anterior está dirigida a relativizar la teoría del riesgo creado que, al tener su origen en el derecho civil, resulta de aplicación innecesaria para la determinación de la responsabilidad extracontractual, en virtud de la teoría de la integridad de la reparación patrimonial presente en las disposiciones constitucionales, según lo ha reconocido el Tribunal Supremo de Justicia.

Pero la sentencia no se pronuncia abiertamente por la innecesariedad de la teoría, sino que invita a la prudencia en la aplicación de la misma, cuando se considere que sea procedente, para luego efectuar la siguiente conclusión:

"Así las cosas, probado como quedó que la Administración conocía la existencia del riesgo por los acontecimientos vividos en el país, y en especial por las amenazas y el sobre recibido por el Magistrado Alirio Abreu Burelli, no tomando las medidas necesarias para evitar daños que se pudieran producir dadas las especiales circunstancias, sino como se indicó tales medidas fueron tomadas después de que ocurrió el accidente, resulta claro para esta Sala que la República actuó negligentemente y en tal virtud es responsable. Así se declara”.

No obstante la admisión con reservas de la teoría del riesgo creado, el Tribunal Supremo de Justicia ha efectuado un llamado a ser muy cuidadosos en su aplicación, al expresar ${ }^{56}$ :

"Aunado a lo expuesto, debe indicarse que la responsabilidad extracontractual de la Administración, debe ser interpretada bajo criterios restringidos, a fin de evitar generalizaciones impropias e inconducentes que excluyan los supuestos necesarios eximentes de la responsabi-

55 Tribunal Supremo de Justicia en Sala Político Administrativa, sentencia 2130, de 9 de octubre de 2001.

56 Tribunal Supremo de Justicia en Sala Político Administrativa, sentencia 1013, de 31 de julio de 2002. 
lidad, tales como, hecho exclusivo de un tercero, culpa exclusiva de la víctima, fuerza mayor o caso fortuito".

La sentencia además de advertir los peligros que se podrían derivar de una aplicación irrestricta de la teoría, indica que en caso de acudirse a ella, deben considerarse los siguientes elementos:

"Se impone entonces siempre un análisis, guardando la debida ponderación o prudencia en la aplicación de la teoría del riesgo, con omisión de la falla o falta del servicio, porque si se extiende o exagera en demasía su aplicación, sin límites, ello podría conllevar a que la administración tenga que hacerse prácticamente responsable de todas las situaciones de daño, lo cual puede establecer una injustificada y excesiva onerosidad sobre la hacienda pública".

En conclusión, aunque se ha admitido la teoría del riesgo creado en la jurisprudencia, la misma se ha aplicado con notable cautela, a los fines de prevenir que la Administración Pública se transforme en la responsable de todos los daños que pueden experimentar las personas en la sociedad actual.

Sin embargo, debe advertirse que esta ponderación debe ser analizada bajo el prisma de la posterior sentencia de la Sala Constitucional del Tribunal Supremo de Justicia ${ }^{57}$.

\section{La responsabilidad por daños causados por las cosas}

Se ha establecido que la Administración Pública genera consecuencias jurídicas tanto por la actividad como por la inactividad, ambas formales o materiales y si estas producen un daño injusto que le sea imputable, deberá responder a la persona afectada, quien tiene el derecho a la indemnización íntegra.

Ahora bien, existen supuestos en los cuales la Administración Pública no es responsable por su actuación u omisión, sino que tal responsabilidad se puede derivar de objetos o bienes, muebles o inmuebles que, siendo de su propiedad o de tercero están bajo su guarda, custodia, cuidado o administración, y que producen un daño injusto en la esfera jurídica de personas distintas de sus titulares o detentadores, quienes tienen derecho a exigir una indemnización por la lesión experimentada.

57 El fallo parcialmente trascrito de 31 de julio de 2002 es anterior a la sentencia 2818, de 19 de noviembre de 2002, de la Sala Constitucional del Tribunal Supremo de Justicia, en la cual se expresó: "De allí que difiera esta Sala del criterio expresado por la Sala Político-Administrativa en la sentencia objeto de revisión cuando expresa que la responsabilidad extracontractual de la Administración debe ser interpretada bajo criterios restringidos a objeto de evitar generalizaciones que lleven a la Administración a asumir la responsabilidad de todas las situaciones de daño y afecten el erario público.

Antes bien, considera esta Sala Constitucional que tratándose la responsabilidad patrimonial del Estado de una garantía constitucional inherente a todo Estado de Derecho, consagrada a favor del particular afectado por la conducta administrativa dañosa, la misma debe ser interpretada por los jueces en forma progresiva y amplia, a favor del administrado. Del análisis de la normativa constitucional vigente, infiere esta Sala que la responsabilidad patrimonial del Estado no debe ser considerada como una garantía en favor de los entes públicos; por el contrario, su consagración constitucional exige que la misma sea interpretada por los jueces en sentido amplio y progresista como una garantía patrimonial del administrado frente a las actuaciones de la Administración generadoras de daño". 
La jurisprudencia administrativa paulatinamente ha avanzado estableciendo la procedencia de la responsabilidad de la Administración Pública por los daños causados por los bienes bajo su guarda.

Así, resulta pertinente traer a colación un caso emblemático, como lo fue Freddy Cabello Sánchez, quien mientras conducía su vehículo en una vía nacional, sufrió un accidente como consecuencia del desprendimiento de su base de una valla de señalización, en virtud que los tornillos que la sostenían se encontraban oxidados, lo que produjo que esta le cayera en la cabeza, causándole la muerte por traumatismo cráneo encefálico.

Durante el juicio, los testigos fueron contestes en declarar que antes del accidente la valla que se desprendió se encontraba en mal estado, que se veía inclinada y que luego del accidente pudieron observar que los tornillos que la sostenían se encontraban partidos y oxidados.

En razón de ello se considera que, teniendo el Ministerio de Obras Públicas la competencia para el mantenimiento de las vías públicas, ella debe extenderse a los accesorios inherentes a tales vías de comunicación, como los elementos de señalamiento vial. Con fundamento en estas premisas, la Corte Suprema de Justicia resolvió que ${ }^{58}$ :

"Comprobada, pues, la obligación de la República de Venezuela de reparar los daños materiales y morales causados a la viuda e hijos de Freddy Luis Cabello Sánchez en razón de la muerte violenta provocada por una cosa inanimada que se encontraba bajo la guarda de la demandada, tan sólo resta determinar el monto de esas indemnizaciones, lo cual pasa a analizar en el capitulo siguiente".

En otro caso célebre en materia de responsabilidad, conocido como Cedeño Salazar, quien, mientras realizaba unos trabajos en la casa de su madre, levantó un tubo que rozó unos cables de alta tensión que se encontraban ubicados en el lugar, sin cumplir con las normas de seguridad al estar más bajos de lo reglamentado, lo que le ocasionó una descarga eléctrica sobre su cuerpo, ocasionándole la muerte.

La madre y la hermana de la víctima, quien también sufrió lesiones en el suceso, demandaron la responsabilidad de la empresa pública prestadora del servicio de energía eléctrica, en virtud de que esta era quien tenía la guarda del tendido eléctrico, lo que la Corte Suprema de Justicia destaca al referirse a la decisión del tribunal de primera instancia, que había dejado establecido lo siguiente ${ }^{59}$ :

"Al efecto, la C.A. de Administración y Fomento Eléctrico (CADAFE) en ningún momento ha negado ser guardián de los conductores eléctricos, bajo los cuales se produjo el accidente ni del fluido eléctrico que por ellos circulaba. Tampoco hay discusión acerca de la causa de la muerte del causante de los demandantes que fue, como se ha dicho, electrocución. La relación de causalidad entre el hecho de la cosa y el daño causado es obvia, puesto que la electrocución

58 Corte Suprema de Justicia en Sala Político Administrativa, sentencia de 19 de junio de 1984.

59 Corte Suprema de Justicia en Sala Político Administrativa, sentencia de 11 de febrero de 1985. 
no puede tener otra causa que no sea una descarga eléctrica, cualquiera que sea su frente o las circunstancias en que alcance el cuerpo de la victima".

En consecuencia, la sentencia reconoce que ha sido correctamente establecida la cuantía de la indemnización por concepto de daño moral concedido a las demandantes.

En otro caso, conocido como Nelson Molina, quien conducía un camión y rozó con un cable de alta tensión, lo que produjo una descarga de energía eléctrica que le produjo quemaduras en su cuerpo, que condujeron a la amputación del antebrazo izquierdo por encima del codo, así como parálisis radial severa del mismo, amputación de la pierna derecha por encima de la rodilla y de la pierna izquierda por debajo de la rodilla, quedando incapacitado. La Corte Suprema de Justicia se pronunció señalando ${ }^{60}$ :

"3. La condición de guardián de la cosa demandada se halla igualmente probada. En efecto, la condición de distribuidora de energía eléctrica que tiene la empresa C.A. de Administración y Fomento Eléctrico (CADAFE) le imprime la calidad de ser guardián de la conducción de esa energía hasta el sitio de consumo. En el itinerario del transporte de esa energía el distribuidor no pierde la cualidad de guardián así los postes puedan encontrarse en terrenos de propiedad privada, ya que no es el propietario del terreno quien puede recoger la energía eléctrica en la planta para trasladarla al sitio final a los fines de su consumo".

En consecuencia, la sentencia estableció la responsabilidad y dispuso el pago de sumas de dinero por concepto de lucro cesante y daño moral.

Un asunto distinto es el caso Ramón Gallardo, quien experimentó daños materiales producto de la ruptura de un tanque del almacenamiento de agua, propiedad del Instituto Nacional de Obras Sanitarias (INOS), que se utilizaba para suministrar el líquido a los inmuebles de la urbanización y que concretamente descargó en la planta baja de su casa millones de litros de agua, produciendo tanto pánico entre los habitantes de la casa como gravísimos daños materiales.

La Corte Suprema de Justicia comienza por establecer que tal hecho constituye un hecho notorio, en virtud de lo cual no debe ser objeto de prueba, y seguidamente procede a determinar la responsabilidad con fundamento en los siguientes argumentos ${ }^{61}$ :

"Esta Sala comparte el criterio según el cual, cuando el daño se imputa al hecho propio de las personas, funciona la responsabilidad civil ordinaria, pero si el daño se imputa como en este caso «a la acción de la cosa», la responsabilidad del guardián no se rige por el artículo 1185 del Código Civil, sino por la disposición especial del artículo 1193 ejusdem, el cual por la naturaleza especial es de preferente aplicación. El fundamento de esta responsabilidad es una presunción de «culpa de la guarda» que la Ley establece contra el custodio, quien sólo puede librarse probando que el hecho fue causado por falta de la victima, el hecho de un tercero, caso fortuito o fuerza mayor ... (omissis)... En el caso de autos, la parte demandada no invocó en su contestación la culpa de la víctima, el hecho de un tercero, el caso fortuito o la

60 Corte Suprema de Justicia en Sala Político Administrativa, sentencia de 7 de marzo de 1989.

61 Corte Suprema de Justicia en Sala Político Administrativa, sentencia de 30 de noviembre de 1994. 
fuerza mayor, ni que la ruina se debiera a falta de mantenimiento o defecto de construcción, que son los unicos medios de excepción de que disponia la parte demandada para exonerarse, por lo tanto según el criterio de esta Sala, queda plenamente probada la culpa y la relación de causalidad del hecho ilicito por los argumentos antes expuestos".

Lo anterior condujo a declarar la responsabilidad y establecer la consiguiente indemnización, -aunque de manera parcial-, reclamada en la demanda.

Casos como estos se han multiplicado a través del tiempo y ponen en evidencia cómo el Máximo Tribunal de la República ha sido conteste en reconocer la responsabilidad de la Administración Pública, por los daños imputables a esta por las cosas bajo su guarda.

\section{La responsabilidad precontractual y contractual}

La responsabilidad contractual ha sido reconocida desde que se admitió la posibilidad de juzgar la existencia de contratos celebrados por la Administración Pública, que no se regían por las reglas de derecho privado, lo que incluso vino a constituir el origen de la distinción entre los contratos administrativos y los contratos privados de la Administración Pública ${ }^{62}$, que tanta polémica han generado en la doctrina científica nacional.

Ello permitió desarrollar la tesis de que en los casos de demandas de cumplimiento, nulidad, validez, interpretación y resolución de los contratos administrativos, los interesados debían plantear la demanda ante los órganos jurisdiccionales administrativos, quienes, conforme a lo dispuesto en la Constitución, eran los competentes para condenar al pago de sumas de dinero y la reparación de daños y perjuicios imputables a la Administración Pública.

En cuanto a la responsabilidad extracontractual, también se ha producido una evolución progresiva, que permite entender que tanto por actos, hechos, omisiones, como por bienes públicos se pueden producir daños y perjuicios a las personas y estos tienen derecho a ser indemnizados o resarcidos, aunque tal afectación a su esfera jurídica patrimonial, no sea derivada de una relación jurídica bilateral preestablecida con la Administración Pública.

Este desarrollo que se inicia desde hace algo más de medio siglo en Venezuela, lo reconoce el Tribunal Supremo de Justicia, al expresar que ${ }^{63}$ :

"En este orden de ideas, debe destacarse que la responsabilidad patrimonial del Estado puede devenir de una obligación contractual o extracontractual, siendo susceptible esta última de reclamación proveniente de una responsabilidad con falta de la Administración por la comisión de un hecho ilicito, o una responsabilidad sin falta, ocasionada por el normal o anormal funcionamiento de los servicios públicos".

Corte Federal y de Casación, sentencia de 5 de diciembre de 1944

63 Tribunal Supremo de Justicia en Sala Constitucional, sentencia 724, de 3 de junio de 2009. 
La sentencia parcialmente transcrita no contiene referencia alguna a la responsabilidad precontractual que, al producirse en el contexto de un procedimiento administrativo para seleccionar a los contratistas, ha sido regulada de manera expresa en el ordenamiento jurídico venezolano.

Es así como, al revisar el articulado de la Ley de Contrataciones Públicas ${ }^{64}$, se contempla la responsabilidad precontractual, al establecer que en los procedimientos administrativos de selección de contratistas, la autoridad contratante siempre puede dar por terminado dicho procedimiento, en el supuesto de no haber firmado el contrato. En tal caso, se establece que si se hubiere efectuado la adjudicación y notificado al destinatario, se deberá proceder a la indemnización con una suma equivalente al monto de los gastos en que incurrió para participar en el procedimiento administrativo. No obstante ese reconocimiento, tal monto es limitado a un porcentaje que no podrá ser superior al cinco por ciento del valor de la oferta.

Para efectuar la indemnización, se requiere que la persona que obtuvo la adjudicación del contrato efectúe la solicitud a la Administración Pública contratante y le suministre los comprobantes de los gastos en que incurrió, dentro del plazo de 30 días que correrán a partir de la notificación de la terminación del procedimiento administrativo. La norma concluye señalando que, en caso de haberse otorgado la adjudicación, si esta no se ha notificado, no procederá indemnización alguna ${ }^{65}$.

No obstante el reconocimiento anterior, resulta necesario mencionar que la limitación apriorística de la indemnización a un porcentaje del valor de la oferta, podría materializar una restricción al principio de reparación integral del daño, establecida en la Constitución y desarrollado por la jurisprudencia.

Como se puede apreciar, la responsabilidad de la Administración Pública se encuentra plenamente reconocida en el plano precontractual, que en definitiva es una modalidad de responsabilidad extracontractual; así también en el plano extracontractual, que no tiene ninguna vinculación con la preparación de los contratos, y en el plano propiamente contractual.

\section{La responsabilidad por violación de normas internacionales}

La República de Venezuela es un Estado federal, conforme a los términos establecidos en la Constitución ${ }^{66}$, en razón de lo cual tanto los órganos que ejercen el Poder Público, como los funcionarios públicos tienen la obligación de garantizar el respeto, goce y ejercicio de los derechos humanos en todo el territorio nacional, en virtud de la cláusula federal contenida en los tratados internacionales en materia de Derechos Humanos, válidamente suscritos y ratificados por la República.

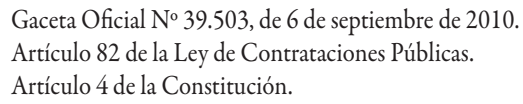


Es así como los órganos que ejercen el Poder Público tienen la obligación de garantizar a todas las personas, con sujeción a los principios de progresividad y sin discriminación, el goce y ejercicio irrenunciable, indivisible e interdependiente de los derechos humanos reconocidos en los tratados internacionales ${ }^{67}$, los cuales gozan de jerarquía constitucional y prevalecen en el orden interno, en la medida que contengan normas sobre disfrute y ejercicio más favorables a los establecidos en la Constitución y leyes de la República, siendo de aplicación inmediata y directa por todos los órganos que ejercen el Poder Público ${ }^{68}$.

Conforme a tales disposiciones, se establece que la República deberá investigar y sancionar legalmente los delitos contra los derechos humanos cometidos por las autoridades públicas, y se consideran imprescriptibles las acciones para determinar los delitos de lesa humanidad, violaciones graves de los derechos humanos, que serán investigados y juzgados por los tribunales penales, así como tampoco prescriben los crímenes de guerra, y en ningún caso podrán ser beneficiados con el indulto o la amnistía ${ }^{69}$.

Igualmente el texto constitucional reconoce que la República tendrá la obligación de indemnizar integralmente a las víctimas de violación de los derechos humanos o a sus herederos, cuando tal violación le sea imputable, en cuyo caso deberán incluir el pago de daños y perjuicios ${ }^{70}$.

A los fines de garantizar esta obligación se deberán adoptar las medidas legislativas y de otra naturaleza para hacer efectivas las indemnizaciones y procurar que los culpables reparen los daños causados. También se reconoce la obligación de garantizar el derecho de las personas a acudir ante los órganos internacionales creados para la protección de los derechos humanos, con la finalidad de solicitar el amparo de sus derechos humanos ${ }^{71}$.

Por otra parte, la Constitución dispone que en el marco de los acuerdos de integración en el ámbito latinoamericano y caribeño, todas aquellas normas que se adopten, se consideren como integrantes del ordenamiento jurídico, siendo de aplicación directa y preferente a la legislación interna ${ }^{72}$.

No obstante la claridad apodíctica de las mencionadas disposiciones constitucionales y del reiterado reconocimiento de la obligación de cumplir con el derecho supranacional producido por las instituciones de la Comunidad Andina, conforme a lo establecido en la Protocolo modificatorio del Tratado de creación del Tribunal de Justicia del Acuerdo de Cartagena, actual Comunidad Andina, se produjo una primera quiebra de esta obligación y en consecuencia del deber de responder, a partir de la denuncia del Tratado de creación de la Comunidad Andina, por parte del gobierno de la República de Venezuela, el 26 de abril de 2006, dando inicio al período de retiro, que finalizó cinco años después, en abril 2011.

\footnotetext{
Artículo 19 de la Constitución.

Artículo 23 de la Constitución.

Artículo 29 de la Constitución.

Artículo 30 de la Constitución.

Artículo 30 de la Constitución.

Artículo 153 de la Constitución.
} 
La segunda quiebra de la obligación de responsabilidad por violación de los tratados internacionales en materia de derechos humanos, que como se ha mencionado gozan de jerarquía constitucional, se ha producido luego de la destitución de cuatro jueces del orden jurisdiccional administrativo, sin garantizarles el pleno ejercicio de sus derechos humanos.

Estas personas, luego de agotar la instancia nacional sin obtener pronunciamiento expedito, y sin dilaciones indebidas, respecto al restablecimiento de los derechos humanos denunciados como violados, fueron a las instancias internacionales y la Corte Interamericana de Derechos Humanos ${ }^{73}$, dispuso lo siguiente:

"16. ElEstado debe realizar los pagos de las cantidades establecidas en la presente Sentencia por concepto de daño material, inmaterial y reintegro de costas y gastos dentro del plazo de un año a partir de la notificación de la presente Sentencia, en los términos de los párrafos 236, 242 y 260 de la misma.

17. El Estado debe reintegrar al Poder Judicial a los señores Juan Carlos Apitz Barbera y Perkins Rocha Contreras y a la señora Ana Maria Ruggeri Cova, si éstos asi lo desean, en un cargo que tenga las remuneraciones, beneficios sociales y rango equiparables a los que les corresponderia el dia de hoy si no hubieran sido destituidos. Si por motivos fundados, ajenos a la voluntad de las victimas, el Estado no pudiese reincorporarlas al Poder Judicial en el plazo de seis meses a partir de la notificación de la presente Sentencia, deberá pagar a cada una de las victimas la cantidad establecida en el párrafo 246 de esta Sentencia.

18. El Estado debe realizar las publicaciones señaladas en el párrafo 249 de esta Sentencia, en el plazo de seis meses a partir de la notificación de la misma.

19. El Estado debe adoptar dentro del plazo de un año a partir de la notificación de la presente Sentencia las medidas necesarias para la aprobación del Código de Ética del Juez y la Jueza Venezolanos, de conformidad con lo expuesto en el párrafo 253 de esta Sentencia.

20. Supervisará la ejecución integra de esta Sentencia y dará por concluido el presente caso una vez que el Estado haya dado cabal cumplimiento a lo dispuesto en la misma. Dentro del plazo de seis meses a partir de la notificación de esta Sentencia, el Estado deberá rendir a la Corte un informe sobre las medidas adoptadas para darle cumplimiento".

En respuesta a este fallo se pronunció la Sala Constitucional del Tribunal Supremo de Justicia $^{74}$, en los siguientes términos:

"Ahora bien, se advierte del fallo de la Corte Interamericana de Derechos Humanos que este órgano pretende que el Estado venezolano indemnice a los ex jueces de la Corte Primera de lo Contencioso Administrativo Ana Maria Ruggeri Cova, Perkins Rocha Contreras y Juan Carlos Apitz, a quienes califica de "victimas" por haber presuntamente sido violados sus derechos individuales; pero en la supuesta constatación por dicha Corte de la violación de los

73 Corte Interamericana de Derechos Humanos, sentencia de 5 de agosto de 2008, Caso Apitz Barbera y otros (Corte Primera de lo Contencioso Administrativo) vs. Venezuela.

74 Tribunal Supremo de Justicia en Sala Constitucional, sentencia 1913, de 18 de diciembre de 2008; ratificada en sentencia 1547 , de 17 de octubre de 2011. 
derechos o libertades protegidos por la Convención, dictópautas de carácter obligatorio sobre gobierno y administración del Poder Judicial que son competencia exclusiva y excluyente del Tribunal Supremo de Justicia y estableció directrices para el Poder Legislativo, en materia de carrera judicial y responsabilidad de los jueces, violentando la soberania del Estado venezolano en la organización de los poderes públicos y en la selección de sus funcionarios, lo cual resulta inadmisible".

La Sala Constitucional, luego de invocar en su argumentación como precedente, una sentencia dictada durante otra dictadura -la de Alberto Fujimori-, por la Sala Plena del Consejo Supremo de Justicia Militar de la República del Perú ${ }^{75}$, procedió a resolver que es:

“1) INEJECUTABLE el fallo de la Corte Interamericana de Derechos Humanos, de fech a 5 de agosto de 2008, en el que se ordenó la reincorporación en el cargo de los ex-magistrados de la Corte Primera de lo Contencioso Administrativo Ana María Ruggeri Cova, Perkins Rocha Contreras y Juan Carlos Apitz B., se condenó a la República de Venezuela al pago de cantidades de dinero y a las publicaciones referidas al sistema disciplinario de los jueces.

2) Con fundamento en el principio de colaboración de poderes (articulo 136 de la Constitución de la República de Venezuela) y de conformidad con lo dispuesto en el artículo 78 de la Convención Americana sobre Derechos Humanos, se solicita al Ejecutivo Nacional proceda a denunciar este Tratado o Convención, ante la evidente usurpación de funciones en que ha incurrido la Corte Interamericana de los Derechos Humanos, con el fallo objeto de la presente decisión".

Con esta sentencia, no solo se asume directamente la irresponsabilidad internacional de la República en caso de violación de derechos humanos, sino que, como muestra de doble irresponsabilidad, por una parte se le plantea al Ejecutivo Nacional que proceda a denunciar la Convención Americana sobre Derechos Humanos, lo que constituye una invitación al retiro del Sistema Interamericano de Derechos Humanos, pretendiendo sustraerse de su ámbito de aplicación y cumplimiento, evitando así tener que responder en caso de futuras condenas, a lo que, en segundo lugar, se suma la designación días antes del fallo comentado de la Sala Constitucional, de tres personas distintas de aquellas que la Corte Interamericana había ordenado restituir en sus cargos de jueces, incluido entre los designados como nuevos jueces, a la persona que representó a la República ante la instancia internacional y que perdió el caso, lo que la Sala Constitucional emplea como coartada para proceder a declarar que la ejecución no podía producirse, en virtud de que los cargos donde debían reincorporarse los jueces que fueron víctimas de la violación de sus derechos humanos no estaban vacantes.

El gobierno nacional asumió la exhortación del Tribunal Supremo de Justicia y el Ministerio de Relaciones Exteriores, cumpliendo las instrucciones de la Presidencia de la República, mediante comunicación dirigida al Secretario General de la Organización de Estados Americanos, el día 6 de septiembre de 2012, procedió a denunciar la Conven-

75 Consejo Supremo de Justicia Militar del Perú, Sala Plena, sentencia de 30 de mayo de 1999, caso Castillo Petruzzi y otros. 
ción Americana sobre Derechos Humanos ${ }^{76}$, con la pretendida aspiración de que cesen sus efectos y sustraerse de la jurisdicción de la Comisión Interamericana y de la Corte Interamericana.

Esta declaración desconoce varias disposiciones de la Constitución, cuya supremacía el gobierno nacional sostiene defender, pues mediante un mecanismo distinto de los que ella misma contempla ${ }^{77}$, tanto el Presidente de la República ${ }^{78}$ como el Ministro de Relaciones Exteriores cumpliendo órdenes de aquél -sin que ello le sirva de excusa ${ }^{79}$ - han pretendido derogar parcialmente los artículos 2 (preeminencia de los Derechos Humanos como valor superior del ordenamiento jurídico), 19 (principio de progresividad), 22 (jerarquía constitucional de la Convención Americana sobre Derechos Humanos) y 339 (obligación de cumplimiento de las exigencias, principios y garantías establecidos en la Convención, en caso de que se decretase un estado de excepción), así como también derogar totalmente el artículo 31 (derecho de acceso y solicitud de protección y amparo de los Derechos Humanos ante los órganos internacionales), todos de la Constitución.

No obstante, a pesar de las consecuencias fácticas de la denuncia, desde la perspectiva internacional el Estado sigue obligado a respetar y cumplir los derechos humanos y los mecanismos de protección y reparación contenidos en los Pactos, Protocolos y Convenciones sobre Derechos Humanos que integran el Sistema Universal, que tiene válidamente suscritos y ratificados, como miembro de la Organización de Naciones Unidas.

En el contexto nacional, el Estado además tiene el deber de cumplir la Constitución que contiene un extenso catálogo de los derechos humanos reconocidos en Venezuela.

De lo anterior ha quedado claro que en la última década, la responsabilidad ha cedido el paso a la irresponsabilidad de la República, por incumplimiento e inaplicación del derecho internacional de la integración y del derecho internacional de los Derechos Humanos.

\section{La responsabilidad por daño moral}

La responsabilidad por el daño moral experimentado por las víctimas o los familiares, consecuencia de la actividad o inactividad imputable a la Administración Pública que produce un daño antijurídico a las personas, ha sido ampliamente desarrollada en la jurisprudencia.

Es así como se recuerda la sentencia que resuelve el asunto planteado por la viuda de la víctima y sus hijos, quienes, entre otras pretensiones, formulaban la condena por el daño

\footnotetext{
Artículo 78 de la Convención Americana sobre Derechos Humanos.

Artículo 333 de la Constitución.

Artículo 236.4 de la Constitución.

9 El artículo 25 de la Constitución señala que "todo acto dictado en ejercicio del Poder Público que viole o menoscabe los derechos garantizados en esta Constitución y la ley es nulo, y los funcionarios públicos y funcionarias públicas que lo ordenen o ejecuten incurren en responsabilidad penal, civil y administrativa, según los casos, sin que les sirvan de excusa órdenes superiores".
} 
moral que habían experimentado por el fallecimiento prematuro de su esposo y padre, respectivamente. La Corte Suprema de Justicia en aquella ocasión expresó ${ }^{80}$ :

"Estas estimaciones las hizo el Tribunal de Primera Instancia con base a razonamientos que sólo podian guiarse por los dictados de su conciencia y su sentido de la justicia, ya que los conceptos de dolor, angustia, miedo y sufrimiento, no pueden ser valorados en metálico de manera exacta, como se ha expuesto supra ciertamente, el dolor moral sufrido por la viuda tuvo que ser mayor que el de los hijos, ya que ella, no sólo presenció el accidente, sino que se encontraba en el vehiculo siniestrado y vio morir trágica y violentamente a su esposo, mientras que los hijos tuvieron del hecho un conocimiento "a posteriori" y referencial, aunque no por ello hayan dejado de sufrir también un daño moral".

Luego la Corte Suprema de Justicia se pronuncia sobre el reconocimiento del daño moral en los siguientes términos ${ }^{81}$ :

"Distinto es el caso de los daños morales derivados del sufrimiento que evidentemente le debió causar a sus padres la trágica y prematura muerte de su hijo de sólo cuatro años de edad. Respecto de tales daños, la prueba del valor de ese sufrimiento no es posible, por lo tanto, la Ley faculta al Juez para fjar el monto, una vez comprobados los elementos que sirvan para demostrar el hecho generador del daño y la culpa de la persona contra quien se reclama".

En un caso similar al anterior, la Corte Suprema de Justicia efectúa la siguiente valoración ${ }^{82}$ :

"Lo que resulta desde todo punto de vista inaceptable para la Sala es el objetivo que se persigue con tal prueba, cual es de demostrar que una persona que carece de recursos económicos no puede reclamar una suma elevada como resultado del daño moral que haya sufrido. Esta manera de pensar no sólo es inconstitucional, desde luego que viola el artículo 61 de la Constitución Nacional, sino que es inhumana y deja mucho que desear en relación a la forma como deben comportarse los representantes de los organismos creados por el Estado para la protección de las personas más necesitadas económicamente"s3.

80 Corte Suprema de Justicia en Sala Político Administrativa, sentencia de 19 de junio de 1984, seguida de la sentencia de 11 de febrero de 1985; y sentencia de 7 de marzo de 1989;

${ }^{81}$ Corte Suprema de Justicia en Sala Político Administrativa, sentencia 14 de febrero de 1991.

82 Corte Suprema de Justicia en Sala Político Administrativa, sentencia 4 de marzo de 1993.

83 Sobre este particular merece la pena destacar el voto salvado del Magistrado Luis Henrique Farías Mata, quien expresa categóricamente: "Las duras palabras empleadas en relación con los apoderados de la parte demandada parecen excesivas al Magistrado disidente. Tienen los abogados el deber de utilizar todos los argumentos que crean favorables a sus representados; no puede negarse, además que en materia de daños morales, nuestros autores y tribunales han sostenido las más variadas tesis, algunas de ellas poco razonables. Por otra parte, en otro contexto, no es contrario a derecho afirmar que uno de los elementos que el Juez debe tomar en cuenta a los efectos de la determinación del monto de la indemnización es, precisamente, la situación económica de las partes. Ello se encuentra previsto expresamente para los casos excepcionales a que se refieren los artículos 1187 y aparte único del 1188 del Código Civil, sobre daños causados por personas sin discernimiento o en estado de necesidad, casos en los cuales el Juez puede acordar sumas mayores si la víctima tiene pocos recursos y el autor del daño ostenta una posición superior.... (omissis)... De modo que, existiendo la tesis de que condenar el pago de daños morales es discrecional y habiendo disposiciones legales que dan relevancia a la situación económica de las partes a los efectos de la determinación del quantum de la indemnización, no es descabellado traer a los autos constancia del nivel de ingresos de la contraparte. Tampoco resulta descabellado afirmar que el grado de satisfacción que una determinada persona puede obtener de una cantidad de dinero, depende, en alguna medida, de la relación que exista entre dicho monto y las sumas que la 
El reconocimiento del daño moral producido por la actividad o inactividad administrativa sigue estando reconocido por los órganos jurisdiccionales, al considerar que, si bien la Constitución establece el resarcimiento patrimonial de los daños que sufran los particulares en cualquiera de sus bienes y derechos, por el funcionamiento de la Administración Pública, ello implica que el daño moral es igualmente indemnizable si es imputable a tal Administración.

En este sentido, cabe recordar el caso Hugo Betancourt, quien fue víctima de atentado terrorista en su sitio de trabajo en la antigua Corte Suprema de Justicia. El Tribunal Supremo de Justicia, al analizar la indemnización por daño moral, estableció ${ }^{84}$ :

“... la indemnización por daño moral encuentra su fundamento en la afectación de carácter intangible desde el punto de vista material que se produce en la esfera inmanente al individuo, tomándose en cuenta para su valoración las circunstancias personales de la victima, es decir, la edad, sexo y el nivel de incapacidad que le produjeron los daños. Este derecho a la indemnización por daño moral no persigue en modo alguno sancionar civilmente al causante del daño-como sucede en otros ordenamientos jurídicos- pues su fundamento es el indemnizar el dolor sufrido por una persona a raíz de la pérdida inmaterial, espiritual o afectiva. De alli que el legislador haya dejado al juez la estimación de la indemnización que merece en cada caso, quien haya resultado dañado moralmente".

Luego, el Tribunal Supremo de Justicia ha expresado respecto a la manera de fijar el monto de la indemnización, lo siguiente ${ }^{85}$ :

“... en casos precedentes en los cuales se ha pretendido una indemnización por concepto de daño moral, la Sala ha señalado que el juez puede reducir o aumentar el monto de la cantidad demandada, atendiendo a criterios o parámetros objetivos que tanto la jurisprudencia como la doctrina han delineado, toda vez que el pago que se acuerda como reparación de los daños morales no responde a la fijación de montos que impliquen una forma de enriquecimiento para la víctima, sino que tiene el único propósito de otorgar un verdadero resarcimiento al daño generado en su patrimonio moral".

De los anteriores fallos, se puede apreciar que la indemnización del daño moral disfruta de pleno reconocimiento, así como también el arbitrio del órgano jurisdiccional para establecer por tal concepto el monto que considere pertinente, teniendo como límites al ejercicio de esta potestad, la sujeción a los principios de razonabilidad, proporcionalidad y motivación de la sentencia.

persona en cuestión esté acostumbrada a manejar. Esto, desde luego, sin perjuicio de que la prueba de las entradas mensuales de la víctima termine desfavoreciendo al demandado, puesto que el Juez podría, por tener el actor ingresos exiguos y el demandado un patrimonio importante, condenar a éste al pago de una suma considerable, en uso de la facultad discrecional que la jurisprudencia ha considerado implícita en el citado artículo 1196".

84 Tribunal Supremo de Justicia en Sala Político Administrativa, sentencia 2130, de 9 de octubre de 2001.

85 Tribunal Supremo de Justicia en Sala Político Administrativa, sentencia 267, de 14 de febrero de 2007, que ratifica la sentencia 128, de 7 de febrero de 2013. 


\section{El nexo de causalidad}

Es sabido que el nexo de causalidad constituye un presupuesto de la materialización de la responsabilidad, lo que supone determinar el vínculo que existe entre la actuación u omisión atribuible a la persona productora del daño y este, es decir, no basta la simple reclamación a una persona plenamente identificada y la demostración de un daño; además, debe demostrarse la relación entre la actividad o la inactividad imputable a la persona cuya responsabilidad se exige y la incidencia de tal comportamiento en la producción de daño.

En tal sentido, la jurisprudencia reiterada ha exigido el cumplimiento del presupuesto de la relación de causalidad para la determinación de la responsabilidad exigida a la Administración Pública.

$\mathrm{Al}$ respecto se puede recordar el caso de la reclamación de responsabilidad efectuada por un paciente tratado en una institución hospitalaria pública, en la cual se señalós6:

"... considera la Sala que las pruebas cursantes en autos no aportan elementos suficientes que demuestren el nexo de causalidad entre el presunto daño ocasionado a la actora y que esa actividad haya sido ocasionado por la demandada, toda vez que de las mismas no se evidenció que la ciudadana María Meneses suministró información referencial falsa 0 tergiversada, ni obró en forma imprudente o excediendo la buena fe, por el contrario, dicha ciudadana, se circunscribió a suministrar a la actora el resultado de los primeros exámenes practicados, y adicionalmente le extendió una referencia a fin de que se le realizara una prueba confirmatoria.

Conforme a lo expuesto, concluye esta Sala que la doctora María Meneses actuó de conformidad con la Ley que rige su profesión, la cual, le otorga un poder discrecional para revelar al paciente la verdad de todo aquello que llegare a su conocimiento, asi como la oportunidad y manera de hacerlo, con lo cual no causó daño moral alguno a la actora. Asi se declara".

En la sentencia que se comenta, el órgano jurisdiccional exonera de responsabilidad a la Administración sanitaria, en virtud de que no encuentra que exista actuación alguna imputable a ella o alguno de sus agentes, que permita inferir una contravención a la Ley del ejercicio de la Medicina que haya podido producir el presunto daño moral que dice haber experimentado la demandante.

En un caso resuelto posteriormente, relacionado con las operaciones de búsqueda y salvamento de los pasajeros sobrevivientes de una aeronave siniestrada, que había efectuado un amarizaje de emergencia en el Mar Caribe, cerca de la costa de Maiquetía, -a escasas 12 millas náuticas-, el Tribunal Supremo de Justicia se pronunció, estableciendo lo siguiente ${ }^{87}$ :

"Sin embargo, debe destacar la Sala que la ocurrencia del accidente no es imputable a la Administración, pues no existe relación de causalidad entre la actuación de ésta y el sinies-

86 Tribunal Supremo de Justicia en Sala Político Administrativa, sentencia 1013, de 31 de julio de 2002.

87 Tribunal Supremo de Justicia en Sala Político Administrativa, sentencia 1087, de 22 de julio de 2009. 
tro de la aeronave YV 539 C, cuyos factores concretos se desconocen, pues sólo consta en las probanzas que cursan en autos que el mismo se produjo por la falla del motor derecho de la aeronave, sin que exista evidencia especifica de la causa de tal desperfecto ...(omissis)... Establecido lo anterior, la Sala, considerando que la deficiente actuación de la Administración consistió en el retardo en las labores de rescate de los sobrevivientes de la aeronave YV 539 C, lo cual según se evidencia de autos incidió al menos en la muerte de algunos de los ocupantes de la avioneta siniestrada, este órgano jurisdiccional debe declarar la responsabilidad de la Administración por su insuficiente funcionamiento en el salvamento de los sobrevivientes del mencionado accidente. Asi se declara”.

Es interesante observar cómo la responsabilidad no se establece por el siniestro de la aeronave, pues no existe en el expediente elemento alguno de convicción que conduzca a efectuar semejante inferencia; la razón por la que se concluye que existe la responsabilidad es consecuencia de la relación que se establece posteriormente entre la muerte de los pasajeros sobrevivientes a tal siniestro y el retardo e ineficacia en las gestiones de ubicación y rescate, mientras todavía estaban flotando vivos en el mar.

Tal como se puede apreciar, el nexo de causalidad ha sido empleado por la jurisprudencia como elemento determinante para establecer o exonerar de responsabilidad a las autoridades administrativas.

\section{El daño injusto}

El daño constituye una lesión, afectación o disminución en la esfera jurídica de los bienes o derechos de las personas. Tal daño puede ser justo cuando la Administración Pública, actuando en ejercicio de sus competencias y con estricta sujeción al interés general, prohíbe una actuación, impone una sanción o extingue un derecho, conforme al ordenamiento jurídico y el afectado tiene el deber de soportarlo, pues se considera un daño justo, en tanto la Administración Pública actúa en cumplimiento de las atribuciones y fines legalmente establecidos, no teniendo en principio en tal supuesto, la obligación de indemnización, reparación o restitución.

Existen supuestos en que el daño puede ser injusto y este se produce bien porque la Administración Pública, actuando lícitamente, causa un daño en la esfera jurídica de las personas, sin que estas tengan el deber jurídico de soportarlo, por tratarse de un sacrificio que excede lo racional o tolerable para una persona individualmente considerada, quien no debe experimentar una lesión en su esfera jurídica ante el provecho que va a obtener la comunidad. También se puede producir el daño por una actuación u omisión ilícita, en cuyo caso no existe ningún título jurídico que le imponga al afectado tolerar tal daño.

El daño debe tener las características de ser cierto, es decir, real, que se ha producido materialmente; debe ser individual, lo que implica que sea singular o individualizable, no general; debe ser antijurídico, en el sentido que el afectado no tiene el deber de so- 
portarlo; y en principio debe ser apreciable en dinero, aunque este último no constituye un requisito insoslayable.

En este orden de ideas, la Sala Político-Administrativa ha establecido respecto a los daños materiales, que ${ }^{88}$ :

“... están constituidosporperjuicios de tipopatrimonial, que la doctrina comúnmente divide en daño emergente y lucro cesante. Éstos consisten, bien en la pérdida experimentada en el patrimonio del acreedor, es decir, en los gastos médicos o de otra naturaleza en que éste pudo haber incurrido por las lesiones físicas o psicológicas que le ocasionó el daño (daño emergente), o en la utilidad que se le hubiereprivado por el incumplimiento de la obligación (lucro cesante).

De tal manera, que el reclamante de los daños materiales debe probar las lesiones actuales y ciertas sufridas, señalando expresamente cuál fue la disminución de su patrimonio, no pudiendo el Juez presumir tales daños económicos."

Continuando con el desarrollo de esa posición, el Tribunal Supremo de Justicia, al pronunciarse sobre la existencia de lucro cesante, ha sostenido lo siguiente ${ }^{89}$ :

"Respecto a la solicitud de indemnización por lucro cesante, debe señalarse que de conformidad con precedentes reiterados de esta Sala (Ver sentencia No 1.005 de 30 de julio de 2002), el lucro cesante comporta un daño resarcible a la persona que directamente fue privada de una utilidad y no puede extenderse a otras que, aún teniendo una expectativa legitima y natural respecto de los aportes al ingreso familiar que pudieran haber recibido de sus padres, dichos aportes no pueden ser estimados bajo circunstancia alguna, dado que resulta imposible prever actitudes y voluntades futuras y mucho menos traducir éstas a lenguaje patrimonial; sobre todo si se tiene muy en cuenta que el trabajo, sus frutos y su aprovechamiento eventual por otros, aún tratándose de los padres, dependen exclusivamente de cada persona. En tal virtud, la Sala estima que no resulta procedente la reparación patrimonial por concepto de lucro cesante demandada. Asi se decide".

Posteriormente, la Sala ha vuelto a referirse a la dimensión del daño, puntualizando lo siguiente ${ }^{90}$ :

"No es procedente la indemnización de daños y perjuicios, cuando el reclamante no acredita suficientemente la existencia de los mismos ni demuestra con datos exactos e irrefutables el porqué de la cuantía en que los fija. Y, ello es así, porque no puede convertirse el derecho a una indemnización en fuente de riqueza indebida o sin causa, con daño injusto del patrimonio del Estado que está obligado tan sólo al abono de lo debido, de lo justo.

El resarcimiento debe consistiry constituir en la atribución de un valor pecuniario (= relativo al dinero) que llene el vacio formado en el patrimonio de la victima, de forma que dicho patrimonio quede en igual o similar situación a aquélla en que se habría encontrado de no haberse producido el daño o la lesión de su derecho".

88 Tribunal Supremo de Justicia en Sala Político Administrativa, sentencia 622, de 21 de mayo de 2008.

89 Tribunal Supremo de Justicia en Sala Político Administrativa, sentencia 1087, de 22 de julio de 2009.

90 Tribunal Supremo de Justicia en Sala Político Administrativa, sentencia 206, de 9 de marzo de 2010. 
Ha agregado la Sala Constitucional del Tribunal Supremo de Justicia, que ${ }^{91}$ :

"El detrimento del afectado debe ser ocasionado por un daño antijuridico y debe entenderse como un efecto pernicioso que, como indica la doctrina y legislación comparada, el afectado no está en el deber juridico de soportar, por lo que la visión objetiva de responsabilidad queda enmarcada en un gravamen que no fue buscado, querido ni merecido por la persona lesionada".

Más reciente, respecto a la actividad de policía de seguridad, que genera una detención ilícita, ha sostenido la Sala Constitucional del Tribunal Supremo de Justicia lo siguiente $^{92}$ :

"... esta Sala advierte que en materia de privaciones ilegitimas de libertad, no existe un sistema propiamente dicho de responsabilidad tarifada o tasada a través de la ley, la cual debería proceder en el ordenamiento juridico en circunstancias extraordinarias que deben ser objeto de reconocimiento, pero que quedarian al margen de toda reparación si se aplicaran los parámetros tradicionales para evaluar la responsabilidad estatal, por lo que su exégesis por parte de los órganos que integran el Poder Judicial, debe corresponder a estándares de interpretación quepermitan que el análisis de tales normas, no derive en la pérdida del derecho o en la desnaturalización de tales regulaciones, como medios para lograr una reparación integral del daño, en el marco del sistema de responsabilidad patrimonial del Estado consagrado en la Constitución de la República Venezuela, reconocido de forma reiterada por la jurisprudencia vinculante de esta Sala”.

Tal como se puede apreciar, la jurisprudencia, en desarrollo del principio de la integridad de la indemnización, reconoce el resarcimiento de todo daño injusto material o moral que experimente una persona en su esfera jurídica, siempre que demuestre los presupuestos concurrentes de la responsabilidad de la Administración Pública.

\section{El derecho a la indemnización integral}

El derecho a la indemnización tiene su origen en la garantía económica de la integridad patrimonial de la propiedad, que se ha construido a partir del reconocimiento del ejercicio de la potestad expropiatoria que la Constitución reconoce puede ejercer el Estado, cuando exista una causa de utilidad pública e interés social que conduzca a la extinción del derecho, o que lo afecte de tal manera que lo desnaturalice en su contenido esencial, hasta hacer nugatorio su ejercicio, goce y disfrute, es decir, que no solo procede justa indemnización en caso de expropiación de bienes de cualquier naturaleza, sino también cuando se lesionan los atributos esenciales del ejercicio del derecho, que producen un daño en el esfera jurídica de su titular ${ }^{93}$.

\footnotetext{
Tribunal Supremo de Justicia en Sala Constitucional, sentencia 189, de 8 de abril de 2010.

Tribunal Supremo de Justicia en Sala constitucional, sentencia 845, de 7 de junio de 2011.

Corte Suprema de Justicia en Pleno, sentencia de 10 de agosto de 1977; de 16 de julio de 1980; de 16 de diciembre de 1981 y de 11 de febrero de 1992.
} 
Avanzado en el desarrollo de estas ideas, la Corte Suprema de Justicia manifestaba lo siguiente $^{94}$ :

"Contemporáneamente los textos constitucionales y legales no circunscriben la indemnización únicamente a la pérdida de la propiedad por expropiación, o por los hechos ilícitos de la Administración, sino que la extienden a cualquier lesión a derechos e intereses legitimos, por ejemplo, las privaciones singulares de los atributos esenciales de la propiedad, a pesar de que provengan de sus actos lícitos. En este sentido, si se sigue el lineamiento clásico, sólo habría indemnización por expropiación, cuando se diera un efecto ablatorio, vale decir, cuando se extinga el dominio como consecuencia del ejercicio de un a potestad expropiatoria o si existen daños por la anormalidad o defectos de los servicios públicos. Sin embargo, el derecho a la indemnización, nace también, cuando se afecten en forma ostensible los atributos fundamentales de la propiedad, que signifique una lesión actual y cuantificable para el titular del dominio. Así, en la expropiación la garantía de la indemnización, tiene su causa en el "despojo patrimonial", por lo que tal indemnización es una carga tal que condiciona la procedencia misma de la expropiación (artículo 101 de la Constitución y $3^{\circ}$ de la Ley de Expropiación por Causa de Utilidad Pública o Social). Por el contrario, la responsabilidad por la lesión causada por la actuación administrativa, descansa sobre el hecho de que, dada la posición del administrado, éste recibe una lesión no procurada. Este régimen de responsabilidad del Estado por sus actos lícitos, aparece en la legislación venezolana en el artículo 63 de la Ley Orgánica para la Ordenación del Territorio,... (omissis)... Conforme a esta posición, que se abrepaso en la mejor doctrina, la limitación que incida en las actividades privadas realizadas por el propietario, como ejercicio de los derechos de uso y disfrute de la propiedad, resultaría indemnizable, aunque no exista expropiación o pérdida de la misma".

Los criterios jurisprudenciales y siguiendo la tradición constitucional, los actuales artículos 6, 140, 141 y 259 de la Constitución reconocen expresamente la responsabilidad que tienen los órganos que ejercen el Poder Público, de donde surge tanto la obligación de reparar los daños o lesiones que causen estos con su actividad e inactividad, sean estas lícitas o ilícitas, así como el derecho a la indemnización integral de los afectados.

\section{La corrección monetaria de la indemnización}

Desde la sentencia líder de la Corte Primera de lo Contencioso Administrativo se reconoció que, cuando el signo monetario con que se iba a pagar la indemnización se deprecia por la inflación y la devaluación, se debe considerar esta circunstancia para mantener inalterado el concepto de valor indemnizatorio y, por tanto, es necesario, a los fines de establecer la indemnización, considerar la depreciación que experimenta el dinero desde

94 Corte Suprema de Justicia en Sala Político Administrativa, sentencia de 27 de enero de 1994. 
que se produce el daño hasta el momento del efectivo pago, para realizar la indexación judicial, pues de lo contrario tal indemnización no será ni justa, ni integral95.

En lo concerniente a la posibilidad de conceder la pretensión de corrección monetaria del monto demandado por concepto de daño moral, en virtud de la pérdida del poder adquisitivo de la moneda, cabe recordar el caso de Luz Magaly Serna Rugeles, quien se desempeñó como enfermera en el Hospital Universitario de los Andes, dependiente del entonces Ministerio de Sanidad y Asistencia Social. Ella sostenía que en 1978 comenzó a presentar síntomas de alteración en su salud y fue sometida a numerosos exámenes médicos, pero no fue hasta 1988 que se le diagnosticó intoxicación mercurial crónica, con elevado porcentaje de mercurio en el cuerpo y, ante la negativa de la Administración sanitaria a internarla en un centro especializado en intoxicación con mercurio y no haber sido sometida al tratamiento a tiempo algunas de las lesiones se tornaron irreversibles, por lo que demandó el daño moral que consideraba haber experimentado.

$\mathrm{Al}$ momento de resolver, la Corte Suprema de Justicia ${ }^{96}$ declaró parcialmente con lugar la pretensión de condena de daños morales intentada contra la República, condenándola a pagar la cantidad de ochenta millones de bolívares (Bs. 80.000.000,00) y ordenó la corrección monetaria desde el 24 de noviembre de 1992, fecha de interposición de la demanda, hasta el 11 de noviembre de 1999, fecha de publicación del fallo. En dicha sentencia se designó como experto al Banco Central de Venezuela para determinar el monto a pagar después de aplicada la corrección monetaria, determinando este que el monto definitivo es la cantidad de setecientos treinta millones doscientos ochenta y nueve mil seiscientos ochenta y nueve bolívares con siete céntimos (Bs. 730.289.689,07) y se decretó la ejecución de la sentencia el 15 de junio de 2000.

No obstante, este criterio de la corrección monetaria del daño moral no se volvió a apli$\operatorname{car}^{97}$ y la actual posición del Tribunal Supremo de Justicia se pronuncia en los siguientes términos ${ }^{98}$ :

“... es preciso destacar que conforme a criterio reiterado en la materia, sostenido por este órgano jurisdiccional y ratificado por la Sala Constitucional, la corrección monetaria de montos acordados como consecuencia del daño moral, resulta improcedente toda vez que [...] las cantidades derivadas de las demandas de indemnización del daño moral no son suscep-

95 Corte Primera de lo Contencioso Administrativo, sentencia de 28 de octubre de 1987; Corte Suprema de Justicia en Sala Político Administrativa, sentencia de 5 de diciembre de 1990; de 27 de enero de 1993 y de 15 de julio de 1993.

96 Corte Suprema de Justicia en Sala Político Administrativa, sentencia 1563, de 11 de noviembre de 1999.

97 No se puede omitir la mención, que el Tribunal Supremo de Justicia en Sala Político Administrativa, sentencia 2130, de 9 de octubre de 2001, caso Hugo Betancourt, asume una posición ecléctica respecto a “... la solicitud de indexación reclamada por la parte actora, [pues] la Sala debe negarla en virtud de resultar improcedente en materia de daño moral ya que la indemnización es acordada por el Juez en la oportunidad de dictar el fallo, sin necesidad de que sea ajustado por el transcurso del tiempo", pero concede una asignación vitalicia que calcula en 30 unidades tributarias, lo que implica que será ajustada anualmente cuando se produzca la modificación de la unidad tributaria, conforme a los criterios técnicos existentes para ello, es decir, que aunque la asignación es fija será objeto de corrección monetaria anual.

98 Tribunal Supremo de Justicia en Sala Político Administrativa, sentencia 1370, de 30 de septiembre de 2009, ratificada en la sentencia 128, de 7 de febrero de 2013. 
tibles de indexación, ya que su estimación es realizada por el juez a su prudente arbitrio, sin necesidad de recurrir a medio probatorio alguno y con fundamento en la valoración de la importancia del daño, el grado de culpabilidad del autor, la conducta de la victima y la llamada escala de los sufrimientos morales, de conformidad con el artículo 250 del Código de Procedimiento Civil, en concordancia con el artículo 1.196 del Código Civil...”.

En conclusión, teniendo actualmente el país la inflación más alta del mundo, que según cifras del Banco Central de Venezuela al 31 de diciembre de 2013, alcanzó el 56\% anual y siendo la indemnización una obligación de valor, deberá ser aplicada la indexación desde el momento de ocurrir el hecho que produce el daño material hasta el momento en que se haga efectivo el pago; en tanto que, en el caso del daño moral, este no será susceptible de indexación, sino de estimación conforme al libre y prudente arbitrio del órgano jurisdiccional.

\section{Los datos estadísticos: cantidad de procesos y cantidad de condenas}

En la segunda mitad del siglo XX se produjo un avance lento pero constante, en el reconocimiento de la responsabilidad de la Administración Pública y, concretamente, en la última década del referido siglo, se llevó a cabo un valioso análisis de la doctrina científica, liderada por el profesor Luis Ortiz Álvarez ${ }^{99}$.

El progreso jurisprudencial en materia de responsabilidad contractual y extracontractual de la Administración Pública, amén de las disposiciones constitucionales que reconocían su procedencia, no siempre estuvo exenta de debate y crítica constructiva dirigida a perfeccionar el régimen jurídico de la responsabilidad.

Durante ese tiempo, las decisiones no fueron muy numerosas, pero sin duda muy valiosas, pues importando más la calidad de las sentencias que la cantidad, se fueron estableciendo paulatinamente los principios que llevaron a abandonar la idea que no valía la pena demandar a la Administración Pública, pues no existía la posibilidad de obtener una sentencia de condena en su contra.

Con la entrada en vigencia de la Constitución de 1999, se ha dicho que aunque esta no realiza una ruptura con respecto a su predecesora, produjo un cambio sobre el tema de la responsabilidad de la Administración Pública, al establecerse un "régimen amplio, integral y objetivo de la responsabilidad del Estado que se erige en garantía de los particulares frente a las actuaciones dañosas de la Administración"100.

No obstante, la realidad indica que justamente los jueces del orden jurisdiccional administrativo han sido los principales obstáculos para avanzar en el desarrollo de la

99 Ortiz Álvarez (1995); Ortiz Álvarez (1997); y más reciente Ortiz Álvarez (2006); y Revista de Derecho Administrativo, números 1 al 20, ed. Sherwood, Caracas, 1997-2003.

100 Tribunal Supremo de Justicia en Sala Constitucional, sentencia 2818, de 19 de noviembre de 2002. 
responsabilidad integral, amplia y objetiva que pretende reconocer a las personas la Sala Constitucional del Tribunal Supremo de Justicia, al leer, interpretar y aplicar las disposiciones constitucionales.

Aunque no existen unas estadísticas oficiales completas, al menos que hayan sido publicadas, del número de causas ingresadas y resueltas entre el $1^{\circ}$ de enero de 2000 y la presente fecha, algún destacado académico se ha tomado la tarea de efectuar durante algún tiempo, un estudio de las sentencias de la Sala Político Administrativa del Tribunal Supremo de Justicia, máxima instancia del orden jurisdiccional administrativo ${ }^{101} \mathrm{y}$ de las decisiones emitidas tanto a favor de las personas cuando actúan como demandantes, como a favor de los órganos que ejercen el Poder Público, en sus distintas manifestaciones cuando actúan como demandados, y ha llegado a la conclusión que los resultados son desoladores, pues menos del cinco por ciento de los casos analizados por él fueron declarados parcialmente a favor de las personas demandantes, lo que implica, en consecuencia, que ni siquiera en los escasos asuntos resueltos a favor de los particulares, estos obtuvieron una satisfacción plena de sus pretensiones de condena de la Administración Pública.

Por supuesto, las estadísticas por si solas únicamente revelan una tendencia en las sentencias, pero sin estudiar cada caso no sirven para determinar la sujeción a Derecho de las sentencias analizadas, pues para ello tendría que realizarse el estudio detenido de cada expediente, verificando los alegatos y pretensiones, los medios probatorios aportados y la congruencia entre lo planteado y decidido, a los fines de determinar la validez intrínseca de la sentencia emitida en cada caso.

\section{Consideraciones finales}

La existencia del Estado de Derecho encuentra como uno de sus pilares, un efectivo sistema de responsabilidad de la Administración Pública que reconozca y garantice los derechos de las personas a ser íntegramente indemnizados, restablecidos, reparados o restituidos en su esfera jurídica subjetiva, siempre que esta se haya visto lesionada o afectada por la actividad o inactividad imputable a los órganos que ejercen el Poder Público, en ejercicio de la función administrativa.

La evolución de la jurisprudencia del orden jurisdiccional administrativo ha transitado de la primera etapa de responsabilidad de la Administración Pública, establecida conforme a las disposiciones del Código Civil, a partir de las sentencias de la Corte Suprema de Justicia ${ }^{102}$, aunque admitiendo en alguna de ellas referencia a cierto grado de autonomía mediante la aplicación de los Principios generales del Derecho Público ${ }^{103}$.

101 Canova González (2009).

102 Corte Suprema de Justicia en Sala Político Administrativa, sentencia de 19 de julio de 1984; ratificadas en sentencias de 11 de febrero de 1985; de 4 de marzo de 1993; de 5 de abril de 1994; de 30 de noviembre de 1994; de 3 de agosto de 1995; de 28 de junio de 1996.

103 Corte Suprema de Justicia en Sala Político Administrativa, sentencia de 27 de enero de 1994; ratificada en sentencia de 25 de enero de 1996 y 23 de noviembre de 1999. 
Esto condujo a la doctrina científica a sostener que se había producido una suerte de paradoja, dado que "por un lado todavía emplean el término «responsabilidad civil», pero por el otro lado cada vez empujan más hacia el sistema de responsabilidad administrativa extracontractual, propio y autónomo del derecho administrativo clásico"104.

Sin embargo, lo que se había sembrado en el voto salvado de la sentencia de la Corte Suprema de Justicia ${ }^{105}$ respecto a la autonomía de la responsabilidad extracontractual de la Administración Pública en el Derecho Administrativo, -pues la responsabilidad contractual tenía un reconocimiento claro ${ }^{106}$ - se va a cosechar plenamente una década después, en las sentencias del Tribunal Supremo de Justicia ${ }^{107}$.

Debe destacarse que incluso con la Constitución de 1999 se ha ampliado la evolución del reconocimiento expreso de la responsabilidad, pues además de la atribuida a la República por la función administrativa, se reconoce de manera general la derivada de la función jurisdiccional y de la función legislativa.

Resulta pertinente resaltar que en esa evolución ha tenido un notable aporte el orden jurisdiccional constitucional en la primera década del siglo XXI, que en aras de garantizar los postulados del Estado de Derecho reconocidos en la Constitución, entre los que se cuenta el principio de responsabilidad, ha tenido que intervenir para corregir algunos fallos errados de la Sala Político Administrativa del Tribunal Supremo de Justicia.

Debe mencionarse que la responsabilidad ha sido reconocida tanto desde la perspectiva material o tangible (daño emergente y lucro cesante) como la inmaterial o intangible (resarcimiento del daño moral, incorporal o afectivo).

En la actualidad, luego de marchas, y contramarchas el régimen jurídico de la responsabilidad de la Administración Pública es mixto ${ }^{108}$, pues concurren en su regulación el sistema objetivo y el sistema subjetivo, correspondiendo declararla al orden jurisdiccional administrativo, conforme a las reglas de distribución de competencias contempladas en la Ley Orgánica de la Jurisdicción Contencioso Administrativa ${ }^{109}$.

Se puede finalizar señalando que hay que tener en cuenta que la eficacia del régimen de responsabilidad de la Administración Pública se encuentra en manos de los órganos

104 Iribarren Monteverde (1992).

105 Corte Suprema de Justicia en Sala Político Administrativa, sentencia de 4 de marzo de 1993, en el voto salvado del Magistrado Luis Henrique Farías Mata se señala que "la responsabilidad patrimonial que puede corresponder a las personas morales de Derecho público por el ejercicio de la actividad administrativa, no es ni general ni absoluta, como se ha dicho en la decisión a menudo considerada - no con todo fundamento - madre del Derecho Administrativo; no se rige, en efecto, directa ni literalmente por las reglas del Código Civil, concebidas para regular las relaciones entre simples particulares; y comporta reglas autónomas y propias, que debe determinar, como ya lo ha hecho, el juez venezolano del contencioso-administrativo, tomando en cuenta la naturaleza del servicio público involucrado, y la necesaria conciliación con el interés general en la prestación del servicio".

106 Corte Federal y de Casación, sentencia de 5 de diciembre de 1944.

107 Tribunal Supremo de Justicia en Sala Político Administrativa, sentencia 1013, de 31 de julio de 2002, ratificada en sentencia 850, de 11 de junio de 2003.

108 Tribunal Supremo de Justicia en Sala Político Administrativa, sentencia 1693, de 17 de octubre de 2007, reiterada en sentencia 206, de 9 de marzo de 2010.

109 Con provecho, Brewer-Carías y HernándeZ-Mendible (2014), pp. 10-220. 
jurisdiccionales administrativos y únicamente su efectivo control constituye la garantía para las personas, tanto de un real restablecimiento de las situaciones jurídicas lesionadas, como de que estos puedan contar con hacer efectivo el derecho fundamental a la Buena Administración.

\section{Referencias Bibliográficas}

Araujo-Juárez, José (2007): Derecho Administrativo. Parte General, Ediciones Paredes, Caracas.

Brewer-Carías, Allan R. (1964): Instituciones fundamentales del Derecho Administrativo y la jurisprudencia venezolana, Universidad Central de Venezuela, Caracas.

Brewer-Carías, Allan R. (1985): Las Constituciones de Venezuela, Centro de Estudios Constitucionales, Madrid.

Brewer-Carías, Allan R. (1992): "Las provincias coloniales y la organización territorial del Estado venezolano”, en: Revista de Derecho Público No 51, Editorial Jurídica Venezolana, Caracas, pp. 5-14;

Brewer-Carías, Allan R., y Hernández-Mendible, Víctor R. (2014): Ley Orgánica de la Jurisdicción Contencioso Administrativa, Editorial Jurídica Venezolana, 2a ed., Caracas.

Canova González, Antonio (2009): La realidad del contencioso administrativo venezolano (Un llamado de atención frente a las desoladoras estadísticas de la Sala Político Administrativa en 2007 y primer semestre de 2008), FUNEDA, Caracas.

Gordillo, Agustín (1998): "Fuentes Supranacionales de Derecho Administrativo", en: Derecho Administrativo. Homenaje al profesor Miguel S. Marienhoff, AbeledoPerrot, Buenos Aires.

Guillermo Andueza, José (1959): El control en Venezuela de los actos ilegales de la Administración Pública, Caracas.

Hernández-Mendible, Víctor R. (2011): "La responsabilidad de la Administración Pública en Venezuela”, en: Responsabilitá Civile e Amministrazione. Uno studio comparato, (Dir. Fracchia, Fabrizio e Botassi, Carlos), Editoriale Scientifica, Napoli.

Hernández-Mendible, Víctor Rafael (2008): "Los principios generales del Derecho en el Derecho Administrativo”, en: Los principios en el Derecho Administrativo Iberoamericano, Netbiblo-Junta de Castilla y León, Valladolid-Salamanca.

Iribarren Monteverde, Henrique (1992): "La Responsabilidad Administrativa Extracontractual” en: Revista de la Facultad de Derecho de la Universidad Católica Andrés Bello $\mathrm{N}^{\circ} 44, \mathrm{UCAB}$, Caracas.

Lares Martínez, Eloy (1963): Manual de Derecho Administrativo, Universidad Central de Venezuela, Caracas. 
Ortiz Álvarez, Luis (1995): La responsabilidad patrimonial de la administración pública, Editorial Jurídica Venezolana, Caracas.

Ortiz Álvarez, Luis (1997): Jurisprudencia de responsabilidad extracontractual del Estado (1961-1997), FUNEDA-Editorial Jurídica Venezolana, Caracas.

Ortiz Álvarez, Luis (2006): “La responsabilidad patrimonial del Estado en Venezuela en la Constitución de 1999 (Visión general sustantiva y el mito del carácter objetivo del sistema)", en: Congreso Internacional de Derecho Administrativo en Homenaje al profesor Luis Henrique Farías Mata, Tomo I, Universidad Católica Andrés Bello, Caracas.

Rodríguez García, A. (1992): “Marco institucional del municipio contemporáneo” en: Revista de Derecho Público N 51, Editorial Jurídica Venezolana, Caracas, p. 56.

\section{Normas Citadas}

Carta Democrática Interamericana, suscrita el 11 de septiembre de 2001, en Lima, capital de Perú, por todos los países de América.

Constitución de 24 de septiembre de 1830.

Constitución de 30 de diciembre de 1999.

Convención Americana sobre Derechos Humanos.

Ley Orgánica de la Jurisdicción Contencioso Administrativa.

\section{XXIII.Jurisprudencia Citada.}

Consejo Supremo de Justicia Militar del Perú, Sala Plena, sentencia de 30 de mayo de 1999, caso Castillo Petruzzi y otros.

Corte Federal y de Casación, en Sala Federal, sentencia de 8 de febrero de 1939.

Corte Federal y de Casación, sentencia de 5 de diciembre de 1944.

Corte Interamericana de Derechos Humanos, sentencia de 5 de agosto de 2008, Caso Apitz Barbera y otros (Corte Primera de lo Contencioso Administrativo) vs. Venezuela.

Corte Primera de lo Contencioso Administrativo, sentencia de 28 de octubre de 1987.

Corte Suprema de Justicia en Pleno, sentencia de 10 de agosto de 1977; de 16 de julio de 1980; de 16 de diciembre de 1981 y de 11 de febrero de 1992.

Corte Suprema de Justicia en Sala Político Administrativa, sentencia de 23 de noviembre de 1999.

Corte Suprema de Justicia en Sala Político Administrativa, sentencia de 5 de diciembre de 1990. 
Corte Suprema de Justicia en Sala Político Administrativa, sentencia de 27 de enero de 1993. Corte Suprema de Justicia en Sala Político Administrativa, sentencia de 15 de julio de 1993. Corte Suprema de Justicia en Sala Político Administrativa, sentencia de 20 de enero de 1983. Corte Suprema de Justicia en Sala Político Administrativa, sentencia de 14 de noviembre de 1963 Corte Suprema de Justicia en Sala Político Administrativa, sentencia de 5 de febrero de 1964. Corte Suprema de Justicia en Sala Político Administrativa, sentencia de 14 de febrero de 1991. Corte Suprema de Justicia en Sala Político Administrativa, sentencia de 25 de enero de 1996. Corte Suprema de Justicia en Sala Político Administrativa, sentencia de 2 de noviembre de 1982. Corte Suprema de Justicia en Sala Político Administrativa, sentencia de 9 de abril de 1987. Corte Suprema de Justicia en Sala Político Administrativa, sentencia de 14 de mayo de 1985. Corte Suprema de Justicia en Sala Político Administrativa, sentencia de 21 de abril de 1999. Corte Suprema de Justicia en Sala Político Administrativa, sentencia de 27 de enero de 1994. Corte Suprema de Justicia en Sala Político Administrativa, sentencia de 25 de enero de 1996. Corte Suprema de Justicia en Sala Político Administrativa, sentencia de 5 de abril de 1994. Corte Suprema de Justicia en Sala Político Administrativa, sentencia de 19 de junio de 1984. Corte Suprema de Justicia en Sala Político Administrativa, sentencia de 11 de febrero de 1985. Corte Suprema de Justicia en Sala Político Administrativa, sentencia de 7 de marzo de 1989. Corte Suprema de Justicia en Sala Político Administrativa, sentencia de 30 de noviembre de 1994.

Corte Suprema de Justicia en Sala Político Administrativa, sentencia de 19 de junio de 1984. Corte Suprema de Justicia en Sala Político Administrativa, sentencia de 11 de febrero de 1985. Corte Suprema de Justicia en Sala Político Administrativa, sentencia de 7 de marzo de 1989. Corte Suprema de Justicia en Sala Político Administrativa, sentencia de 4 de marzo de 1993. Corte Suprema de Justicia en Sala Político Administrativa, sentencia de 11 de noviembre de 1999.

Corte Suprema de Justicia en Sala Político Administrativa, sentencia de 19 de julio de 1984. Corte Suprema de Justicia en Sala Político Administrativa, sentencia de 11 de febrero de 1985. Corte Suprema de Justicia en Sala Político Administrativa, sentencia de 4 de marzo de 1993. Corte Suprema de Justicia en Sala Político Administrativa, sentencia de 5 de abril de 1994. Corte Suprema de Justicia en Sala Político Administrativa, sentencia de 30 de noviembre de 1994. 
Corte Suprema de Justicia en Sala Político Administrativa, sentencia de 3 de agosto de 1995.

Corte Suprema de Justicia en Sala Político Administrativa, sentencia de 28 de junio de 1996.

Procuraduría General de la República, Dictamen de 14 de abril de 1975. 